\title{
Construction and Characterization of an Indoor Smog Chamber for Measuring the Optical and Physicochemical Properties of Aging Biomass Burning Aerosols
}

\author{
Damon M. Smith ${ }^{1}$, Marc N. Fiddler ${ }^{2}$, Kenneth G. Sexton ${ }^{3}$, Solomon Bililign ${ }^{2,4 *}$ \\ ${ }^{1}$ Applied Sciences and Technology Program, North Carolina A\&T State University, Greensboro, NC 27411, USA \\ ${ }^{2}$ NOAA-ISET Center, North Carolina A\&T State University, Greensboro, NC 27411, USA \\ ${ }^{3}$ Department of Environmental Sciences and Engineering, Gillings School of Global Public Health, University of North \\ Carolina at Chapel Hill, Chapel Hill, NC 27514, USA \\ ${ }^{4}$ Department of Physics, North Carolina A\&T State University, Greensboro, NC 27411, USA
}

\begin{abstract}
We describe here the construction and characterization of a new combustion-chamber system (the NCAT chamber) for studying the optical and physicochemical properties of biomass burning (BB) aerosols. This system is composed of a $\sim 9 \mathrm{~m}^{3}$ fluorinated ethylene propylene (FEP) film reactor placed in a temperature-controlled room that uses a tube furnace to combust biomass fuel samples under controlled conditions. The optical properties are measured using a cavity ringdown spectrometer and nephelometer. Aerosol number density and size classification used condensation particle counter, and differential mobility analyzer. Other analytical instruments, used include $\mathrm{NO}_{\mathrm{x}}, \mathrm{O}_{3}, \mathrm{CO}$, and $\mathrm{CO}_{2}$ analyzers, a gas chromatograph, and particle filter samples for determining the physicochemical and morphological properties. The construction details and characterization experiments are described, including measurements of the BB particulate size distribution and deposition rate, gas wall loss rates, dilution rate, light intensity, mixing speed, temperature and humidity variations, and air purification method. The wall loss rates for $\mathrm{NO}, \mathrm{NO}_{2}$, and $\mathrm{O}_{3}$ were found to be $(7.40 \pm 0.01) \times 10^{-4}$, $(3.47 \pm 0.01) \times 10^{-4}$, and $(5.90 \pm 0.08) \times 10^{-4} \mathrm{~min}^{-1}$, respectively. The $\mathrm{NO}_{2}$ photolysis rate constant was $0.165 \pm 0.005 \mathrm{~min}^{-1}$, which corresponds to a flux of $(7.72 \pm 0.25) \times 10^{17}$ photons $\mathrm{nm} \mathrm{cm}^{-2} \mathrm{~s}^{-1}$ for $296.0-516.8 \mathrm{~nm}$, and the particle deposition rate was $(9.46 \pm 0.18) \times 10^{-3} \mathrm{~min}^{-1}$ for $100 \mathrm{~nm}$ mobility diameter BB particles from pine. Preliminary results of the single scattering albedo of fresh and aged $\mathrm{BB}$ aerosols are also reported.
\end{abstract}

Keywords: Biomass burning aerosols; Optical properties of aerosols; Smog chamber; Single scattering albedo; Fresh and aged aerosols.

\section{INTRODUCTION}

Biomass burning $(\mathrm{BB})$ is one of the largest sources of black carbon (BC), or absorbing aerosols, in the atmosphere, with as much as $30 \%$ of aerosol mass belonging to $\mathrm{BC}$ (Andreae et al., 1998; Moosmüller et al., 2009; Bond et al., 2013). While it is well known that $\mathrm{BB}$ aerosols contribute to climate forcing, much is still unknown about the extent of this forcing, owing to the high level of uncertainty regarding BB aerosol optical properties (Andreae and Merlet, 2001; Koch et al., 2009; IPCC, 2013). This uncertainty is partially due to the difficulty in quantifying the amount of light absorption and scattering by aerosols, which depends on their size, chemical composition, age, humidity, and the

\footnotetext{
* Corresponding author.

Tel.: 336-285-2328

E-mail address: Bililignsol@gmal.com
}

wavelength of incident light (Kanakidou et al., 2005; Kim and Paulson, 2013; Harvey et al., 2016).

Biomass burning is a global phenomenon, and the contribution of BB aerosols in the atmosphere is the highest in the tropics (Shi et al., 2015) with around 55\% of the global contributions to BB aerosols coming from Africa (Ichoku et al., 2008; Roberts and Wooster, 2008; Schultz et al., 2008; Roberts et al., 2009; Lamarque et al., 2010; van der Werf et al., 2010). While the optical properties of BB aerosols produced by several North American biomass fuels have been and are being investigated, both in the laboratory and in field campaigns (Hodzic et al., 2007; Mack, 2008; McMeeking et al., 2009; Yokelson et al., 2009; Levin et al., 2010; Mack et al., 2010; Liu et al., 2014), BB aerosols for African fuels were only investigated in field studies (Formenti et al., 2003; Liousse et al., 2010). To our knowledge, there have not been any laboratory studies of the optical properties of BB aerosols from fuel sources common in Africa. The goal for the construction of this chamber is to measure optical properties of BB aerosols 
obtained by combusting biomass fuels from Africa. Smog chambers provide a controlled environment to study the formation and the evolution of specific compounds and particles produced from specific fuel sources of interest by isolating the influence of emissions, meteorology, and mixing effects.

There have been several studies on the physicochemical properties of BB particles in ambient investigations. Size and chemical compositions of wood-fire particles have been shown to change rapidly during the daytime, where photochemical oxidation increased the organic aerosol (OA) fraction (Zauscher et al., 2013). Cloud condensation nuclei $(\mathrm{CCN})$ activity has been found to be impaired by photochemistry (Engelhart et al., 2012; Giordano and AsaAwuku, 2014). Given that aerosol properties are strongly influenced by atmospheric processing, studies of only fresh soot are insufficient and characterization of aged particle properties in a controlled chamber is needed. This study focuses on methods to establish baseline measurements under dry $(0 \%$ relative humidity $(\mathrm{RH}))$ conditions for future planned studies at different values of RH.

The total mass of atmospheric aerosol is dominated by OA $(20-90 \%)$ and is mostly composed of secondary organic aerosols (SOA) (Kanakidou et al., 2005; Jimenez et al., 2009; Zhang et al., 2011; Gentner et al., 2017), which are produced from the atmospheric oxidation and processing of volatile organic compounds (VOCs) (Robinson et al., 2007; Gentner et al., 2012). A smaller fraction of OA is directly emitted as primary organic aerosol (POA) (Hallquist et al., 2009).

POA, while typically treated as nonvolatile and nonreactive, can be aged through evaporation, oxidation, and condensation processes to form SOA (Robinson et al., 2007). Recent experiments have demonstrated that POA from BB contains semi-volatile compounds, which can evaporate during dilution (May et al., 2013). The cooling of particles upon introduction into the chamber can cause the semi volatile organics to condense on the particles. Due to the presence of semi- and low-volatility organics in BB emissions, freshly emitted particles from wood combustion are coated with organic matter (Tissari et al., 2008; Torvela et al., 2014). The coating thickness often substantially increases due to the condensation of secondary organic matter formed either from anthropogenic or from biogenic organic precursor gases in the atmosphere (Akagi et al., 2012; Tiitta et al., 2016). The magnitude of vapor wall loss has not been considered in most smog chamber studies, since these values are not constrained (Bian et al., 2015). Recently, Zhang et al. (2014) showed that the vapor wall loss can underestimate SOA formation, making it necessary to consider this loss when introducing $\mathrm{BB}$ smoke into chambers. Since the initial focus of this work was POA, we did not consider vapor wall loss here. For measurements of fresh soot, the chamber is clean and free from typical atmospheric pollutants. Initial measurements are as close as we can get to POA before aging takes place, while not sampling hot, concentrated gases.

Smog chambers (both indoor and outdoor) have been used, beginning in the 1960 s, to study atmospheric processes in controlled environments, such as BB emissions (Kamens et al., 1984; Hennigan et al., 2011; Bian et al., 2015), SOA production (Carter et al., 2005; Babar et al., 2016), diesel exhaust (Weitkamp et al., 2007), and cigarette smoke (Schick et al., 2012). As opposed to field measurements, the aging process can be studied over longer times in a chamber with greater temporal accuracy and sampling frequency. While some chamber designs, specifically bag chambers, can be difficult to clean, the design and construction of our reactor makes it easy to remove individual panels for either cleaning or repair as needed.

Construction of smog chamber (inner reactor) walls can use a variety of materials, such as stainless steel (Akimoto et al., 1979; Wang et al., 2011) and fluorinated ethylene propylene film (FEP) (Cocker et al., 2001; Carter et al., 2005; Babar et al., 2016). FEP film is the most widely used for large chamber designs due to its transparency in the ultraviolet (UV) spectrum, flexibility under changes in pressure, chemical inertness, and economic feasibility (Wu et al., 2007; Wang et al., 2014). While outdoor chambers provide the most realistic conditions when it comes to the solar spectrum, repeatability of experiments is poor, with many changing variables that depend on the time of year, angle of the sun in the sky, and other weather conditions. Indoor chambers have the advantage of temperature and humidity controls, as well as consistent light intensity (Babar et al., 2016). Modern ultraviolet bulbs, while not having the same spectra as solar light, can be characterized to create accurate models of atmospheric conditions. However, it is also worth noting that the difference between the artificial and solar spectra may lead to different photolysis rates for some reactions (Takekawa et al., 2003; Carter et al., 2005).

In this paper, we describe construction and characterization of an indoor smog chamber built in our laboratory at North Carolina A\&T State University (hereafter referred to as the "NCAT chamber") to study the optical and physicochemical properties of $\mathrm{BB}$ aerosols. In Section 2, we describe the combustion-chamber system, its construction and the details of its operation. In addition, we describe how BB aerosols are produced and introduced into the chamber and how the aerosols are sampled for measuring their broadband optical properties (absorption, extinction, and scattering) as a function of particle size and age. In Section 3, we describe the chamber characterization experiments, including gas and particle wall loss, where white pine wood is used as a fuel for the purposes of comparison with similar chambers. Finally, we present preliminary measurements of single scattering albedo (SSA) as a function of wavelength from 500 to $570 \mathrm{~nm}$ for $\mathrm{BB}$ aerosols produced by combusting eucalyptus in a tube furnace at $500^{\circ} \mathrm{C}$ under two different aging conditions.

\section{DESCRIPTION OF CHAMBER AND FACILITY}

\section{Chamber Facility}

The NCAT chamber is located on one end of our $175 \mathrm{~m}^{3}$ lab, on the opposite side of the room from the vents connected to the building's HVAC system. The chamber is placed as close as possible to test mixture preparation 
sources (tube furnace and gas cylinders) and monitoring instruments to minimize injection and sample line losses. Typical lab temperatures are between 17 and $21^{\circ} \mathrm{C}$, with a relative humidities between $30 \%$ and $60 \%$. Under normal operating conditions, the chamber remains near $0 \%$ humidity (below the detection limits of our instrument), having temperatures close to room temperature while the UV lights are off. With no flows to or from the chamber, humidity increases from near $0 \%$ to near $7 \%$ after 24 hours. Room temperature varies by only a degree or two during normal chamber operations.

\section{Chamber Construction}

The chamber system is composed of two parts: the inner reactor and the outer frame. The reactor is made of 12 rectangular frames connected by hex bolts to form a box having inner dimensions (length $\times$ width $\times$ height) of $2.36 \mathrm{~m} \times 1.85 \mathrm{~m} \times 2.06 \mathrm{~m}$, for a volume of $\sim 9 \mathrm{~m}^{3}$. Each frame is made of wood (having a cross section of 1.5 in $\times$ $1.5 \mathrm{in})$ and wrapped in fluorocarbon film (50 in (width) $\times$ $125 \mu \mathrm{m}$ (thickness), 500A FEP 100, DuPont), which is secured by staples to the back of the wooden frame. The frames are attached to each other so that the inner surface of the reactor is completely covered by the FEP film, leaving all wood surfaces facing the exterior, while the FEP film itself is compressed between panels (using bolts approximately every 6 in) to form an airtight seal. Some of the frames were reinforced by steel angle iron to straighten out the wood and provide a more rigid structure for the reactor. With this design, no heat seals are necessary, which can be expensive and is prone to failure from flexing, which can further result in leaking. The reactor was configured so that an individual panel can easily be detached from the chamber for either cleaning or repair. Cinder blocks are used to elevate the reactor, so that it is centered with respect to the outer frame and to allow for airflow under the reactor for an even temperature distribution.

Two smaller steel panels were attached to the wooden frames on opposite sides of the reactor, flush against the FEP film, to support stainless steel bulkhead fittings for injection and sampling lines. The FEP film, again, served as a seal for these fittings. While the structure of the reactor is rigid, the FEP film walls are flexible, always maintaining nearly constant room pressure in the chamber, and allowing the chamber to operate as a "batch reactor". Although it is assumed that the chamber is airtight, it is more likely that there are small leaks in the chamber, which would allow room air to mix with chamber air. For this reason, the chamber is kept at a slight positive pressure during experiments to ensure that any leaks would be from the chamber into the room. In this way, chamber air does not become contaminated. Rising humidity in the chamber is used to determine if air is leaking into the chamber, due to the difference in $\mathrm{RH}$ between chamber air and room air. If a leak becomes too large, or if the FEP film is punctured, the frame in question can be removed and repaired.

The outer frame of the chamber is made of steel angle iron, having dimensions (length $\times$ width $\times$ height) of $2.55 \mathrm{~m}$ $\times 2.45 \mathrm{~m} \times 2.48 \mathrm{~m}$, which is primarily used for mounting the UV lights and protective coverings. There are two rows of eight light fixtures spaced evenly along the two opposite sides of the chamber. Each fixture holds two bulbs (30watt UVA, $356 \mathrm{~nm}$ centered spectrum, 36 in (length), F30T8/350BL/ECO, Sylvania). Chamber temperature is elevated slightly during operation of the UV lamps and is described in more detail below. Protective Masonite is attached to the outer frame on all sides of the chamber, including the ceiling, except for two windows surrounding the injection and sampling panels which are left uncovered for visual inspection of the chamber, and the floor, where the Masonite is attached directly to the wooden frame of the reactor. The inner surface of the Masonite is covered with aluminum foil to reflect and scatter most of the light emitted from the UV lamps surrounding the chamber to simulate uniform irradiance.

\section{Air Purification}

Room air can be drawn into the chamber through a 3 in (diameter) PVC pipe, fitted with a dust filter to keep out contaminants and dust. The laboratory exhaust system is connected to the chamber via a check-valve with a gated valve used as the exhaust port. This serves to evacuate the chamber with either the room air for primary flushing or clean air for thorough chamber cleaning. This room air input is primarily used to quickly evacuate the chamber after a burn has been completed. To generate clean air, compressed house air, having very low humidity $(\sim 0 \%)$, is passed through a $0.01 \mu \mathrm{m}$ activated carbon filter (4GNN4, Speedaire), followed by a zero-air generator (74730, Aadco Instruments), and a ballast tank (Aadco Instruments). The generator is capable of a maximum flow rate of $30 \mathrm{~L} \mathrm{~min}^{-1}$ and removes any particulates, hydrocarbons, $\mathrm{NO}_{\mathrm{x}}$, and $\mathrm{SO}_{x}$ from the air, while the ballast tank's volume keeps pressure fluctuations, and, by extension, flow rate fluctuations, to a minimum. As provided by the zero-air generator manufacturer's specifications, the gas purity is less than $1 \mathrm{ppb}$ for $\mathrm{O}_{3}$ and $\mathrm{CO}$ and less than $0.5 \mathrm{ppb}$ for $\mathrm{SO}_{2}, \mathrm{H}_{2} \mathrm{~S}$, $\mathrm{NO}, \mathrm{NO}_{2}, \mathrm{NH}_{3}$, and both methane and non-methane hydrocarbons. Airflow to the chamber is controlled by a high-flow rotameter (EW-32033-16, Cole-Parmer), which is capable of flow rates greater than $60 \mathrm{~L} \mathrm{~min}^{-1}$ and is used to balance flows going into the chamber with flows coming out of the chamber. Since the rigidity of the chamber frame keeps the FEP film walls from completely collapsing in on itself, flow rates going into and out of the chamber must remain balanced (or slightly positive, as stated above). While zero-air is sent directly to the chamber after the ballast, air used for other systems is pressure regulated with a single stage regulator (4ZM13, Grainger).

\section{Gas and Particle Injection}

Additional gases, such as commercially prepared gas cylinders of $\mathrm{NO}$ and $\mathrm{NO}_{2}$, can be injected via a second low-flow rotameter (EW-32033-16, Cole-Parmer) with a maximum flow of $1.25 \mathrm{~L} \mathrm{~min}^{-1}$. Concentrations can be calculated from timed injections, certified reagent gas concentration, flow-rate, and chamber volume. A three-way valve between the rotameter and chamber input can be set 
to exhaust, chamber, or off. In the exhaust position, the flow rate can reach equilibrium before switching to the chamber position, allowing for accurate measurement of injections if the elapsed time is known. Other chemical compounds, such as high purity aromatic hydrocarbons can be injected in the liquid phase by syringe through a rubber stopper into a glass U-tube. If necessary, these chemicals can be evaporated by heating the U-tube. A portion of the airflow from the zero-air generator can be diverted through the U-tube to flush the chemicals into the chamber. Gases injected in this manner are used to simulate atmospheric conditions. A mixing fan is mounted below these inputs on the inside of the reactor, which generally produces a well-mixed volume within 15 to 20 minutes after an injection.

Most laboratory studies using smog chambers utilize large combustion chambers (Bian et al., 2015) or residential wood stoves (Grieshop et al., 2009) to generate BB aerosols from combustion. Others use hoods to sample smoke in a more ambient environment (Singh et al., 2016b). While these methods are useful in determining the broader impact of BB, they possess too many poorly constrained variables. Even when a single fuel type is used, there remain contaminants in the surrounding air. Additionally, different parts of the same fire may be undergoing different burning stages, which have distinctly different combustion profiles. To avoid these issues, we have employed a tube furnace, described in detail below, which allows us to combust a measured amount of biomass at a specific temperature to more accurately investigate variations in burning stages.

$\mathrm{BB}$ aerosols are generated by combusting wood samples in a tube furnace. The furnace (HST120300-120SN, Carbolite Gero) holds an $85 \mathrm{~mm}$ (OD), $80 \mathrm{~mm}$ (ID), and $750 \mathrm{~mm}$ (length) quartz working tube and has a heated region of $300 \mathrm{~mm}$. Stainless steel mounts and ceramic insulation plugs on either end enable the introduction and sampling of gasses. BB combustion and aerosol generation using a tube furnace allows us to produce aerosols under controlled burning conditions (temperature, air flow, oxygen content, and amount of fuel burned) and gives us the ability to clearly visually differentiate brown carbon (often formed at around $450-500^{\circ} \mathrm{C}$ ), black carbon (formed around $650-800^{\circ} \mathrm{C}$ ), and other forms (mixed brown/black carbon) at intermediate temperatures. In our experiments we used samples that vary in size from $0.1 \mathrm{~g}$ to $2 \mathrm{~g}$. Samples have been left in a hood to dry out for over a year. We did not attempt to measure the moisture content in the current work for the purposes of chamber characterization; however, we plan to do that in future work.

Although we have not conducted experiments with varying oxygen concentration, we can adjust this value from normal concentrations to effectively $0 \%$ by mixing pure nitrogen with air to reduce the oxygen available for combustion. Furnace temperature can be adjusted from room temperature to $1000^{\circ} \mathrm{C}$. It was found that ignition of samples did not begin until between $400^{\circ} \mathrm{C}$ and $450^{\circ} \mathrm{C}$ under normal oxygen conditions. Smoldering was detected near $500^{\circ} \mathrm{C}$, while flaming typically occurred at higher temperatures. Although there is no clear distinction between purely smoldering or flaming fires, $800^{\circ} \mathrm{C}$ was used for flaming since little to no smoldering occurred.

Airflow through the furnace is regulated by two mass flow controllers (MFC, Sierra Instruments), one each for clean air and nitrogen, with a combined flow rate of $10 \mathrm{~L} \mathrm{~min}^{-1}$. Clean air is supplied by house compressed air that passed through the zero-air generator, while nitrogen comes from a compressed cylinder (industrial grade nitrogen, UN1066, Airgas National Welders). The furnace is preheated to $500^{\circ} \mathrm{C}$ before the introduction of biomass samples. These samples are placed in a quartz combustion boat (FQ-BT-03, AdValue Technology), weighed and pushed into the center of the furnace with the aid of tongs, before replacing the input insulator and flange. The smoke and gases produced from combustion are sent directly to the chamber via a heated $\left(200^{\circ} \mathrm{C}\right)$, and 0.25 in (OD) stainless steel transfer tube. After introduction, they undergo cooling and dilution in a similar fashion to natural processes, as opposed to step-wise dilution and cooling, which introduces a hysteresis in the condensation of semi-volatile species.

\section{Particle Sampling and Optical Property Measurements}

Biomass burning particles are taken from the FEP environmental chamber via graphite impregnated silicone tubing before entering a $710 \mu \mathrm{m}$ impactor inlet $(3.8 \mu \mathrm{m}$ (diameter) cut point), neutralizer, and long differential mobility analyzer (DMA; Model 3080, TSI), where the aerosol is size selected. Flow through the entire system $\left(0.58 \mathrm{sL} \mathrm{min}^{-1}\right)$ is produced by a pump within the waterbased condensation particle counter (WCPC; Model 3787, TSI) and the DMA sheath flow is $2.8 \mathrm{~L} \mathrm{~min}^{-1}$ in single blower mode. Aerosol flow then enters a ring-down cavity, where the aerosol extinction is measured over a range of wavelengths. The extinction coefficient $\alpha_{\text {ext }}\left(\mathrm{m}^{-1}\right)$ is measured by the cavity ring-down system (CRDS), and the extinction cross section $\sigma_{\text {ext }}\left(\mathrm{m}^{2}\right.$ particle $\left.{ }^{-1}\right)$ is found using $\alpha_{\text {ext }}$ and the number density of particles, $N_{C R D}$ (particles $\mathrm{cm}^{-3}$ ), in the cavity. After the CRDS, aerosol scattering coefficients are measured at 453, 554, and $698 \mathrm{~nm}$ using the integrating nephelometer (Model 3563, TSI), with particle concentration measured by the WCPC. Collectively, we have dubbed this system the Aerosol Optical Properties Measurement (AOPM) setup, and it has been extensively characterized (Singh et al., 2014).

The absorption cross section is derived from the difference between the scattering and extinction cross sections. SSA is found by dividing the scattering by the extinction coefficient and adjusting for the relative number density in each instrument. Alternatively, the CPC can be attached directly after the DMA, where it is used to collect size distribution spectra of the BB aerosol (i.e., as a scanning mobility particle sizer (SMPS). When using the DMA, the impact of large, multiply charged particles on measured cross sections should be considered. We conducted a very detailed calibration and error analysis of the system used for optical property measurements of soot (Singh et al., 2014). SMPS spectra are corrected for multiple charging effects using built-in software algorithms. We have shown that SSA can be altered by less than 0.018 (Singh et al., 
2016b; Poudel et al., 2017). This analysis was performed for $200 \mathrm{~nm}$ particles; since there were direct measurements of SSA for $200 \mathrm{~nm}$ particles and $400 \mathrm{~nm}$ particles (i.e., those whose mobility in the +2 -charge state would match the +1 -charged, $200 \mathrm{~nm}$ particles). We have determined the distribution of mobility diameters, at one standard deviation, for each size selected while sampling from the chamber (sheath flow of $2.8 \mathrm{~L} \mathrm{~min}^{-1}$ ), and these values are included in Table 3 (Poudel et al., 2017).

Additional sampling lines are used to measure ozone, nitric oxides, carbon monoxide, carbon dioxide, and hydrocarbons using the analyzers listed in Table 1. Measurements of NO, $\mathrm{NO}_{2}$, and $\mathrm{O}_{3}$ are calibrated before and after a set of experiments, and those calibration factors are averaged to determine resulting concentrations. Fig. 1 provides schematics of the chamber and the full experimental set-up. Sampling lines are also used to collect particulates via impinger (7540-04 and 7542-10, AGI-4, Ace Glass Inc.) and filters ( $2 \mu \mathrm{m}$ [pore], SF18040, Tisch Environmental). Filter samples have been imaged by a Tunneling electron microscope (TEM) to determine their morphology for modeling refractive indices and optical properties using the $T$-matrix code (Poudel et al., 2017) and Raleigh-Debye-Gann (RDG) code will be used in future studies to determine morphology of aged African BB particles.

\section{RESULTS AND DISCUSSION}

The main limitation of chamber experiments is that particles and gas-phase species may be lost to chamber walls on timescales that are shorter than those of the atmospheric processes being studied (Bian et al., 2015). Therefore, before use, chambers must be characterized to reduce uncertainties caused by the loss of gases and particles in the chamber walls, as well as "background reactivity" which possibly includes surface chemistry which can generate gases, including reactive radical species (Carter et al., 2005; Weitkamp et al., 2007). Both particlephase and vapor-phase wall losses must be considered in chamber experiments involving BB. Measuring the wall loss rate for organic compounds would be difficult with the current suite of available instrumentation, so it has not been performed in this work.

The characterization experiments conducted for the NCAT chamber are described below and results are compared with similar chambers. These experiments were performed several times over a period of weeks to months and the results were consistent.

\section{Chamber Mixing, Flushing, and Cleaning}

A fan (12 VDC spark free marine in-line electric blower, 3 in Yellowtail, Shurflo) is used to thoroughly mix chamber injections with chamber air. The fan is rated to $3.40 \mathrm{~m}^{3} \mathrm{~min}^{-1}$ and was used at $25-33 \%$ of maximum power by adjusting a variable voltage regulator. The injections of $\mathrm{NO}$ and $\mathrm{NO}_{2}$ were made using $\sim 54 \mathrm{ppm}$ and $80 \mathrm{ppm}$ of $\mathrm{NO}$ and $\mathrm{NO}_{2}$ (Airgas/National Welders), respectively, at $1 \mathrm{~L} \mathrm{~min}^{-1}$ for $20 \mathrm{~L}$, giving an injection volume of $20 \mathrm{~L}$ for all experiments. This corresponds to a targeted concentration of $0.12 \mathrm{ppm}$

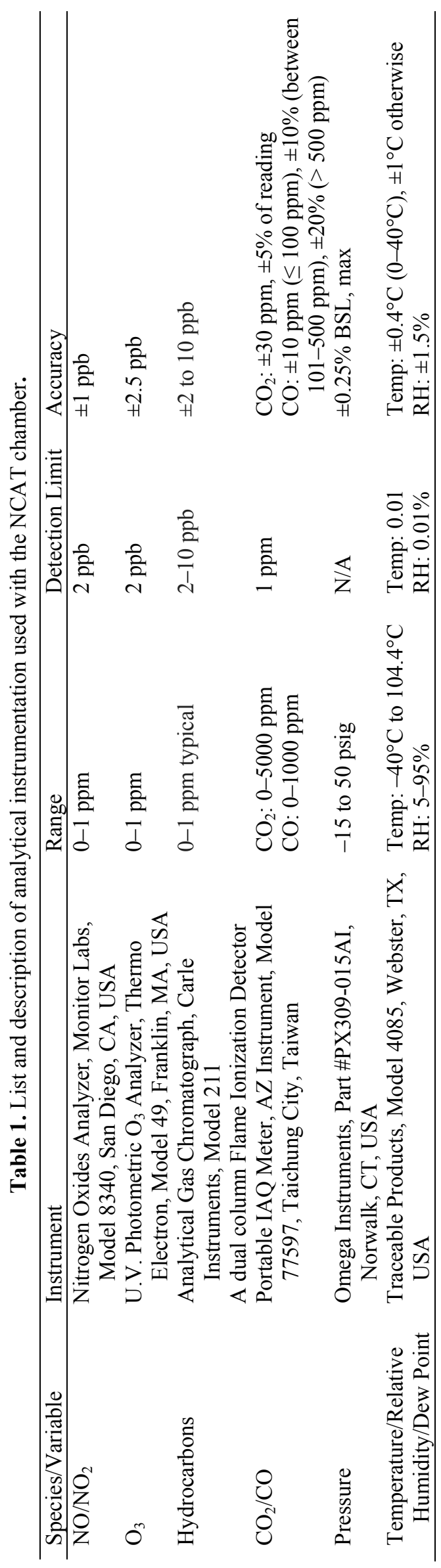




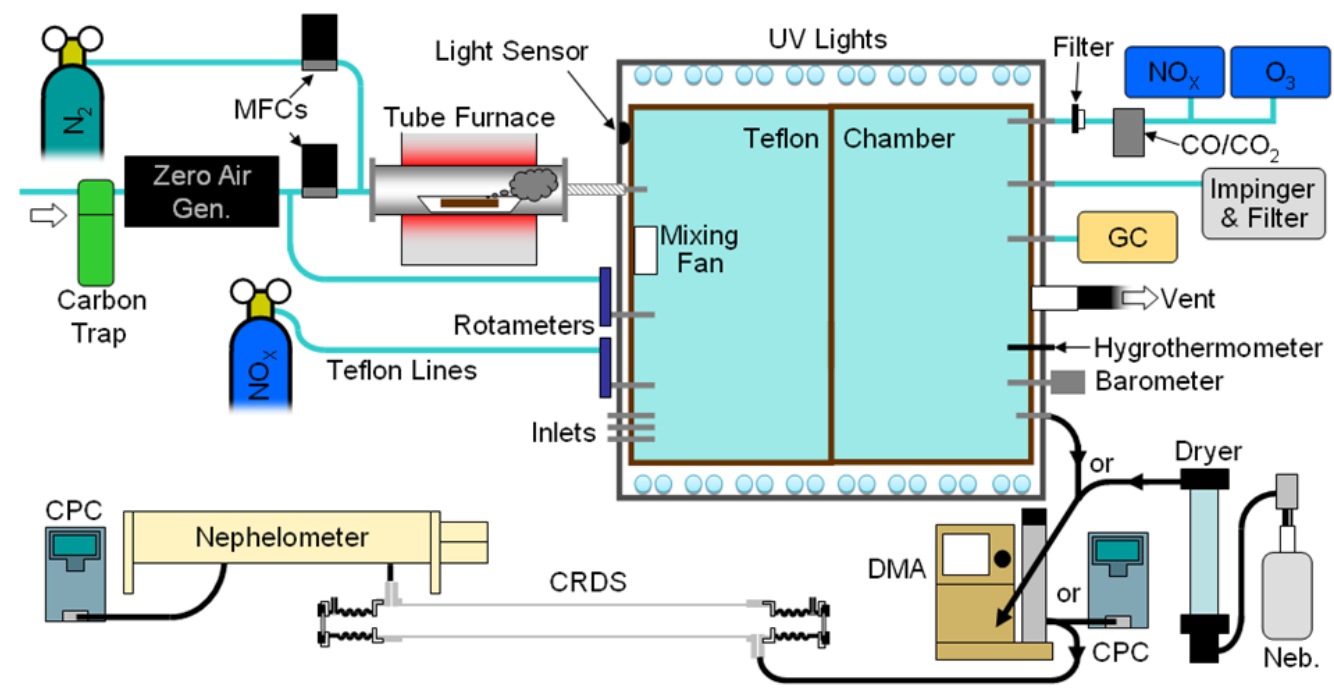

Fig. 1. Schematics of the NCAT Chamber with all inputs and sampling lines, including analytical instruments and optical properties measurement facility (lasers not shown).

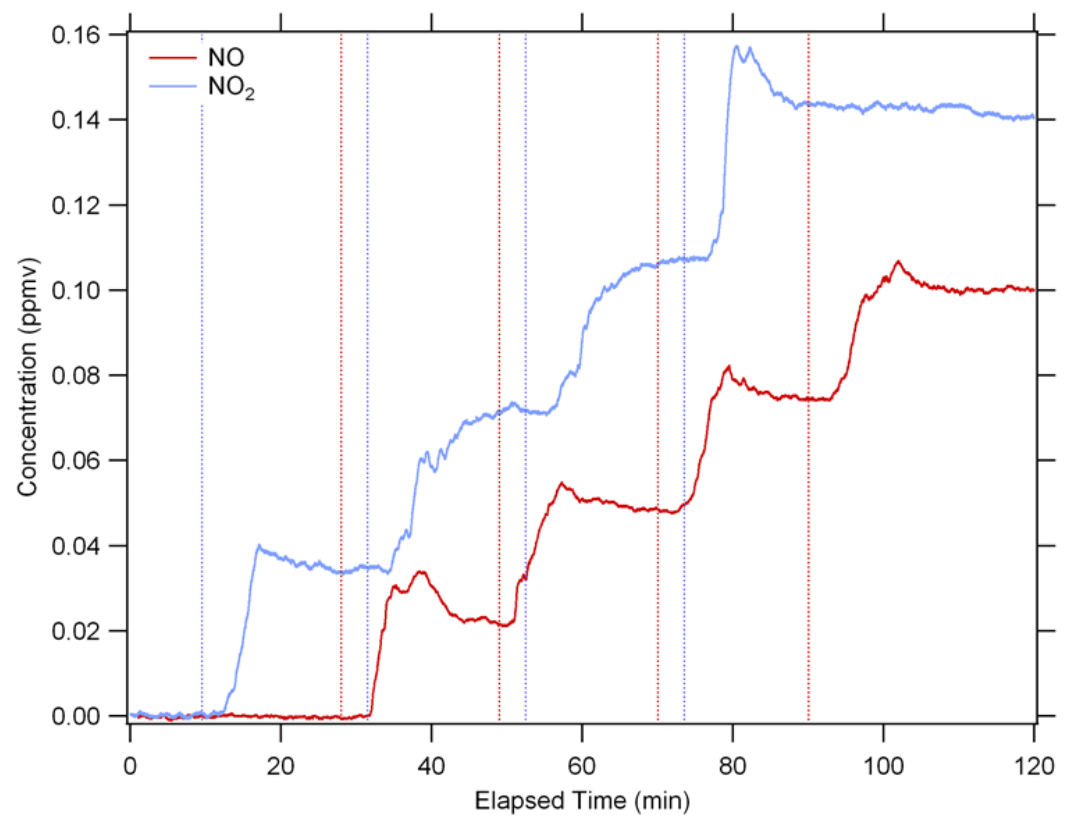

Fig. 2. Injections and response (mixing) time for $\mathrm{NO}$ and $\mathrm{NO}_{2}$ concentrations, done on different days. Vertical lines show injection times, with each injection lasting for 5 minutes.

in the chamber for NO and $0.18 \mathrm{ppm}$ in the chamber for $\mathrm{NO}_{2}$. Fig. 2 shows four injections with 5-minute durations (for a total of 20 minutes of injection), spaced out every 20-30 minutes, with each injection labeled as a vertical line. The figure shows how much time elapses between the injection of a gas and its stabilization in the chamber, including any delay from sampling lines. These gases become well mixed after 15 minutes, as shown in Fig. 2. The actual mixing time is nearly the same as the mixing time reported by other indoor chambers (Wang et al., 2014; Babar et al., 2016), which exhibit mixing times of 2-3 minutes. Based on the available literature, the mixing time seems to be independent of the size of the chamber. The mixing fan rotation speed has been shown to provide better mixing but causes an increase in wall loss (Carter et al., 2005; Wang et al., 2011). Wall loss measurements did not begin until concentrations of the gas had peaked and leveled off.

Unlike gases, when particles are introduced into the chamber, they do not become well mixed (i.e., have a relatively stable size distribution) until 60-90 minutes after injection. This may be due in part to rapid agglomeration, coagulation, and particle growth. A heat map showing size distribution as a function of time is provided as a supplementary figure (Fig. S1). These findings are consistent with those of Kalogridis et al. (2018), which show that BB aerosol particles take approximately 2 hours to reach the same level of diffusion in the chamber as in the ovens where BB is initially combusted. 
After an experiment, the chamber is flushed with air from the zero-air generator at $30 \mathrm{~L} \mathrm{~min}^{-1}$. An equal flow leaves the chamber through a gate valve and exhaust line that connects to the duct of the fume hood. While the vent line is equipped with a fan that is identical to the mixing fan, it is not typically used. At this rate, it usually takes less than 48 hours to remove all trace gases to reach acceptable zero values. Irradiation is not currently being used to clean the chamber since no contaminants are found after 48 hours. Particulates can take up to 72 hours to be removed completely at the same flow rate. Particle removal was monitored using the SMPS and the chamber was considered clean when particle concentrations were lower than the limit of detection; hence, the longer time for particle removal from the chamber.

\section{Wall Loss Rates of Gases}

Typical chamber losses include dilution, vapor and particle deposition, gravitational settling, collisions with the walls of the chamber, agglomeration of smaller particles into larger ones, and leaks from the chamber (Crump and Seinfeld, 1981; Kamens et al., 1984). Particle loss rates are generally lower for larger chambers due to a smaller surface-area-to-volume ratio.

Contamination was a large source of error in early experiments, leading to evacuable chamber designs. It is now common practice to condition chamber walls, especially FEP walls, by flushing the chamber with pure air and irradiating it to remove volatile particles (Akimoto et al., 1979; Grieshop et al., 2009). Off-gassing of $\mathrm{NO}_{\mathrm{x}}$ and other contaminants can also increase uncertainty for low sample concentrations (Carter et al., 2005; Wang et al., 2014). Proper chamber evacuation or flushing is key to removing contaminants left behind after each experiment. Ozone, hydrogen peroxide, and nitrogen oxide are also sometimes used to react with these residual species in order to maintain chamber cleanliness (Babar et al., 2016).

Adsorption of gases on the chamber walls is the primary cause for the decrease of gas concentrations in the chamber. Wall loss rates of $\mathrm{NO}, \mathrm{NO}_{2}$, and $\mathrm{O}_{3}$ were evaluated by injecting $0.12 \pm 0.01 \mathrm{ppm}$ of $\mathrm{NO}$ and $0.18 \pm 0.01 \mathrm{ppm}$ of $\mathrm{NO}_{2}$ during separate experiments and continuously monitoring their decay in the dark and near zero $\mathrm{RH}$, as shown in Fig. 3. While the wall loss rate of $\mathrm{O}_{3}$ was similarly calculated, the initial concentration of ozone injection is unknown due to the large volume of our chamber and the small amount of $\mathrm{O}_{3}$ produced by the lamp (11SC-1, Spectroline) inside our ozone generator. The ozone generator produces $0.126 \mathrm{ppm}$ of ozone at $1.98 \mathrm{sL} \mathrm{min}^{-1}$. Assuming an average laboratory temperature of $19^{\circ} \mathrm{C}$ and $1 \mathrm{~atm}$ of pressure, we calculate that the device produces $1.05 \times 10^{14}$ molecules $\mathrm{O}_{3} \mathrm{sec}^{-1}$. Ozone injections took over 3 days to generate high enough concentrations in the chamber to measure the wall loss rate. It is likely that the injection rate was only slightly higher than the dilution rate. Wall loss rates are obtained by considering the wall loss as a first order process. To determine the total decay of a species in the gas phase, the natural log of its relative concentration is plotted over time, as shown in Eq. (1):

$$
\ln \left(\frac{x(t)}{x(0)}\right)=-k_{t o t} t
$$

where $x(0)$ is the initial concentration of a species, $x(\mathrm{t})$ is its concentration at a given time $t$, and $k_{t o t}$ is the total decay rate constant. When plotted this way, $k_{t o t}$ is the negative of the slope. The dilution rate constant, $k_{d}$, for each species can

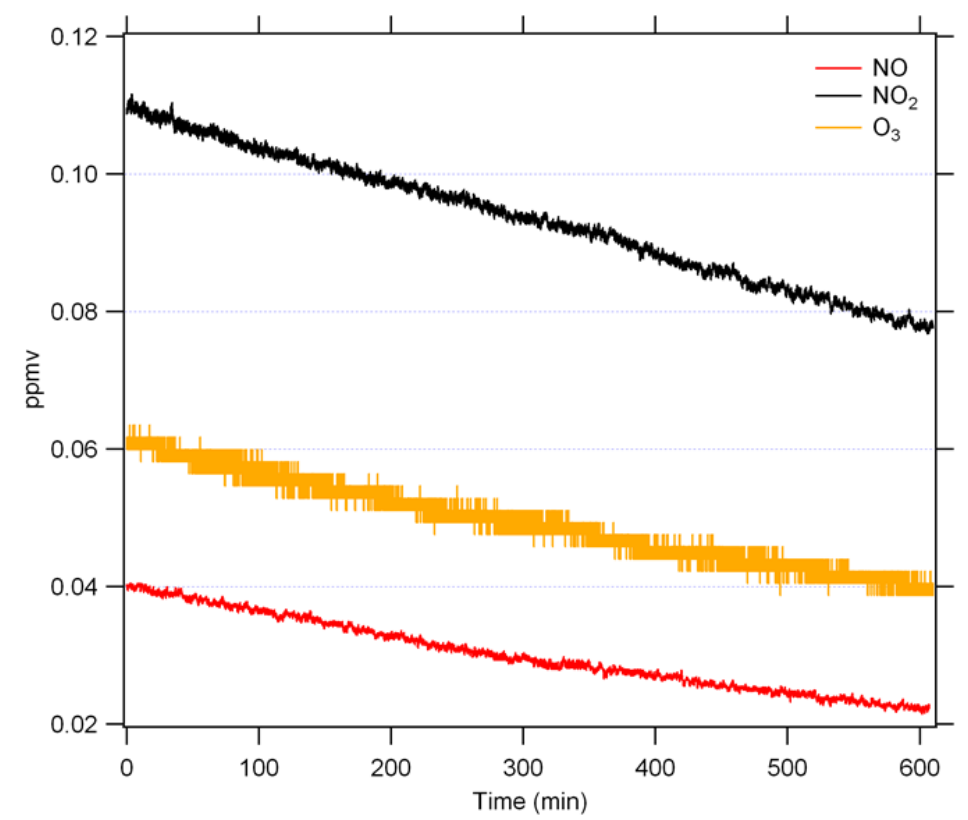

Fig. 3. In the above experiment, the loss rate constant (wall loss plus dilution) was $(1.12 \pm 0.001) \times 10^{-4},(5.73 \pm 0.0023) \times$ $10^{-4}$, and $(6.92 \pm 0.0011) \times 10^{-4} \mathrm{~min}^{-1}$ for $\mathrm{NO}, \mathrm{NO}_{2}$, and $\mathrm{O}_{3}$, respectively. This corresponds to lifetimes of 14.9, 29.1, and 24.1 hours, respectively. 
be determined by summing the sampling flow rates $f_{i}$ for the chamber and dividing them by the chamber volume $V$ :

$$
k_{d}=\frac{\sum_{i}\left(f_{i}\right)}{V}
$$

Since this factor is independent of concentration, it can be used for all species. It is then subtracted from $k_{\text {tot }}$ to get the wall loss rate, $k_{w l}$, for the species:

$$
k_{w l}=k_{t o t}-k_{d}
$$

This factor includes losses due to gravitational settling, impaction with the walls, and leaks from the chamber. For the NCAT chamber, loss rate constants for $\mathrm{NO}, \mathrm{NO}_{2}$, and $\mathrm{O}_{3}$ are $(7.40 \pm 0.01) \times 10^{-4},(3.47 \pm 0.01) \times 10^{-4}$, and $(5.90 \pm$ $0.08) \times 10^{-4} \mathrm{~min}^{-1}$, respectively. Table 2 shows comparisons with similar chambers which represents the averages of several measurements. The errors are one standard deviation $(1 s)$ of these repeated measurements. It is possible to lower wall loss by minimizing surface area to volume ratios, using inert wall materials and attempting to isolate the sampled flow from the walls (Bruns et al., 2015). However, our results are slightly faster than chambers with lower surface area to volume ratios. A possible reason for this is that gas transfer towards the walls are driven by the turbulence inside the chamber (La et al., 2016), which is a result of fan position and speed. Since fan speeds were not provided for all chambers, wall loss comparisons become difficult.

The leak rate of the chamber was measured by injecting an inert gas into the chamber and examining its decay rate. The chamber was brought to $10 \mathrm{ppmv}$ of $\mathrm{CO}$, from a cylinder of 200 ppm CO in $\mathrm{N}_{2}$, and a supplemental flow of $3.0 \mathrm{~L} \mathrm{~min}{ }^{-1}$ was applied to balance instrument sampling. The decay was monitored for over 18 hours. The rate constant for all loss processes (sampling plus leaking) was $(8.440 \pm 0.002) \times 10^{-4} \mathrm{~min}^{-1}$. From this, a total leak rate was determined to be $4.6 \pm 0.2 \mathrm{~L} \mathrm{~min}^{-1}$ (accuracy limited by the rotameter). This rate is likely due to over pressurizing the chamber and small leaks at the corner of each panel, where the Teflon is folded over itself.

\section{Particle Wall Loss Rate and Size Distribution}

Biomass burning particles produced in a tube furnace were introduced into the chamber as described in the section "Gas and particle injection." To enable comparison with other chambers, white pine wood was chosen. It was weighed to $\sim 500 \mathrm{mg}$ and placed in a quartz combustion boat that was in turn placed at the center of the furnace. After the initial combustion of biomass, multiple peaks are seen in the size distribution of the resulting BB aerosol. Both the number of peaks and the diameters they correspond to shift apparently at random as the particles are being mixed inside the chamber. The peak total volume occurred at 45 minutes after introduction and was 1.97 $\times 10^{12} \mathrm{~nm}^{3} \mathrm{~cm}^{-3}$. The peak aerosol surface area occurred at 20 minutes after introduction and was $4.33 \times 10^{10} \mathrm{~nm}^{2} \mathrm{~cm}^{-3}$. At 100 minutes, where Fig. 4 begins, the concentrations

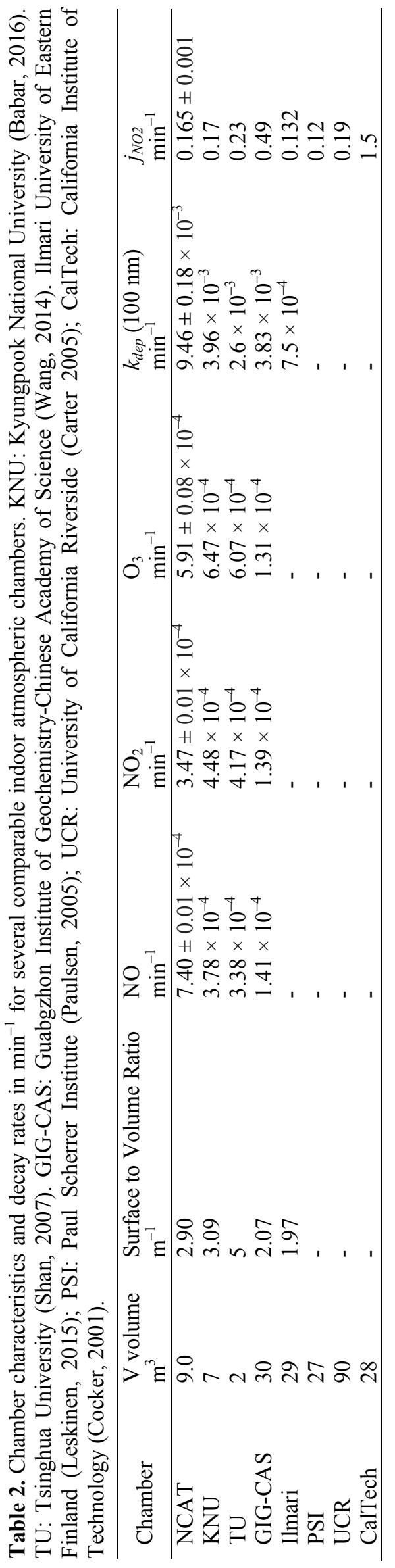


were $1.92 \times 10^{12} \mathrm{~nm}^{3} \mathrm{~cm}^{-3}$ and $3.32 \times 10^{10} \mathrm{~nm}^{2} \mathrm{~cm}^{-3}$ for the volume and area concentration, respectively. After $\sim 60$ 90 minutes, the size distribution resolves into a single lognormal distribution with a peak particle mobility diameter near $246 \mathrm{~nm}$ for pine. The total particle concentration was $\sim 1.5 \times 10^{5}$ particles $\mathrm{cm}^{-3}$ after mixing. Even under dark, dry conditions (i.e., the UV lamps are off and near zero RH), this distribution continues to shift towards larger particle sizes, reaching peak mobility diameters of $\sim 340 \mathrm{~nm}$ after 7.5 hours. This changing distribution can be seen in Fig. 4.

For determining the particle wall loss, focus was given to $100 \mathrm{~nm}$ particles, since these would have the largest removal rates and could be compared to previous measurements in other chambers. As with the gas wall loss rates, it was assumed particle wall loss also followed a first order process and is dependent on concentration and particle size. When $100 \mathrm{~nm}$ particles from white pine wood combustion (shown as the black trace in Fig. 4) were examined, however, they did not follow a first-order decay. Further analysis was done on a larger time range, 25-1510 minutes, and excluded data points with a concentration of zero. Several rate laws, with integer and factional rate orders, were modeled, but none sufficiently represented the particle number density over time. It was found that an offset double exponential decay did reproduce the observations, whose form is given by Eq. (4):

$$
N_{t}=y_{0}+A_{1} e^{-\left(t-t_{0}\right) / \tau_{1}}+A_{2} e^{-\left(t-t_{0}\right) / \tau_{2}}
$$

where $N_{t}$ is the number concentration in particles $\mathrm{cm}^{-3}$ with diameter of $100 \mathrm{~nm}$. We define $\mathrm{k}_{\mathrm{dep}}\left(D_{p}\right)$ as the wall loss rate constant of a particle with diameter $D_{p}$. The resulting fit can be seen in Fig. 5 and seems to well represent the concentration data. The resulting fit parameters were $y_{0}=$ $509.72 \pm 75.6, A_{1}=(3.9408 \pm 0.0369) \times 10^{5}, \tau_{1}=30.495 \pm$ $0.286 \mathrm{~min}, A_{2}=(1.1578 \pm 0.0386) \times 10^{5}, \tau_{2}=105.69 \pm$ $2.05 \mathrm{~min}$, and $t_{0}=25 \mathrm{~min}$. It is likely that two different first-order processes are occurring - one being wall loss and the other being coagulation. The resulting loss rate constants are $(3.28 \pm 0.03) \times 10^{-2} \mathrm{~min}^{-1}$ for $k_{1}$ and $(9.46 \pm 0.18) \times$ $10^{-3} \mathrm{~min}^{-1}$ for $k_{2}$. It is likely that $k_{2}$ represents the particle wall loss rate constant, $k_{\text {dep }}\left(D_{p}\right)$, since its value is comparable, albeit slightly larger, than other chambers that measured the loss rates of $100 \mathrm{~nm}$ particles. For example, the $30 \mathrm{~m}^{3}$ Guangzhou chamber (Wang et al., 2014) had a wall loss rate constant of $3.83 \times 10^{-3} \mathrm{~min}^{-1}$, and for the $7 \mathrm{~m}^{3} \mathrm{KNU}$ chamber (Babar et al., 2016) it was $3.96 \times 10^{-3} \mathrm{~min}^{-1}$. A smaller value of $7.5 \times 10^{-4} \mathrm{~min}^{-1}$ was reported for the $29 \mathrm{~m}^{3}$ Ilmari chamber (Leskinen et al., 2015). This is much lower than most reported particle wall losses. There were no mixing fans in the Ilmari chamber, which could explain the difference. Mixing fans can enhance wall deposition by increasing turbulence inside the chamber. The wall loss rate was faster initially and leveled off after $\sim 4$ hours in the NCAT chamber. Similar observations were reported in the Ilmari chamber (Leskinen et al., 2015).

It is likely that the size distribution changes are due to a competition between wall loss and particle coagulation, with subsequent formation of larger particles. For polydisperse aerosol number loss (i.e., when the total particle volume concentration $\left(\mathrm{nm}^{3} \mathrm{~cm}^{-3}\right.$ ) was plotted), a good fit was found for a first order decay. The loss rate constant for this process was $(1.34 \pm 0.02) \times 10^{-3} \mathrm{~min}^{-1}$ which corresponds to a lifetime of 12.4 hours. If one assumes that particle volume is conserved (i.e., that condensation or evaporation

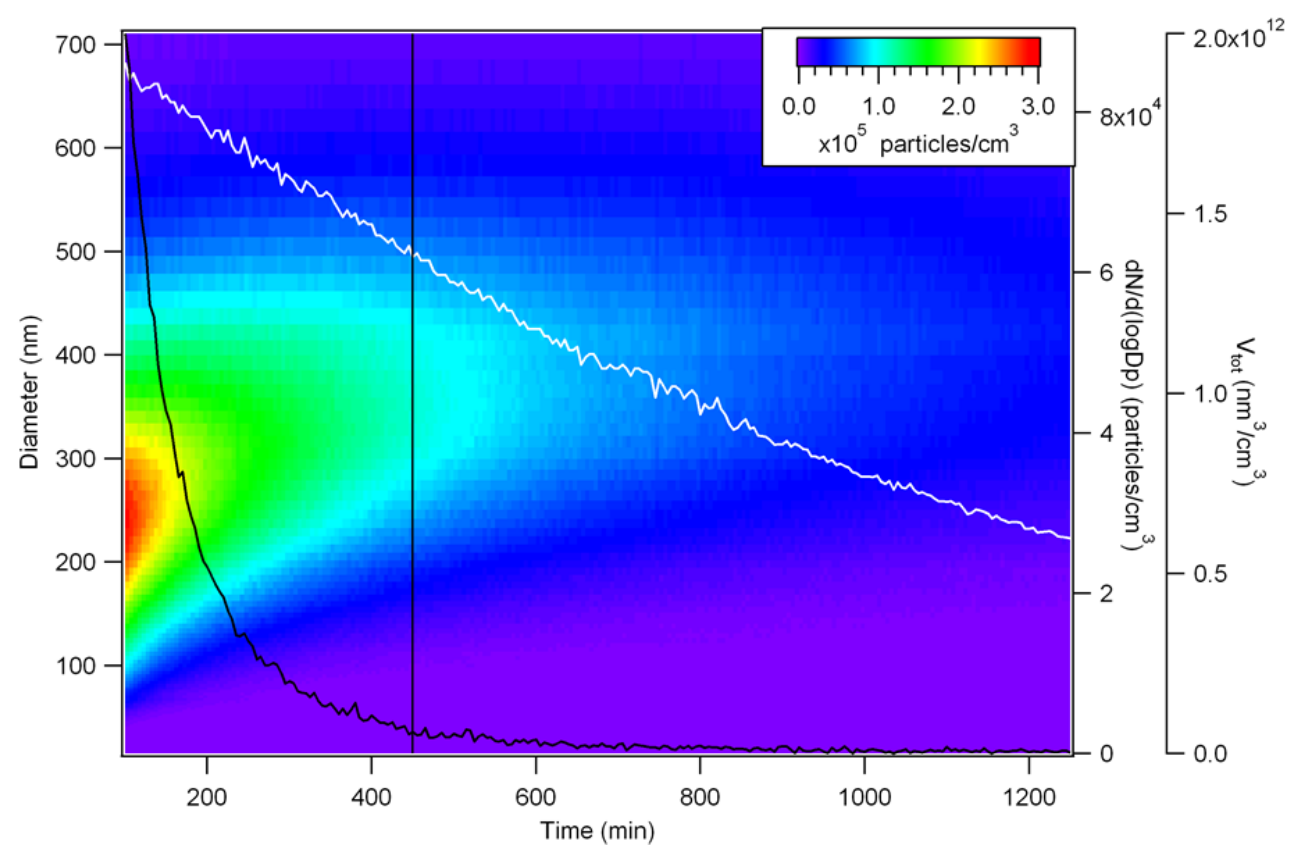

Fig. 4. The number density size distribution of pine combustion over time (background) with particle loss at $D_{p}=100 \mathrm{~nm}$ (black) and aerosol volume loss (white) as measured by the water-based condensation particle counter (WCPC). Size distribution stabilizes around $\mathrm{t}=450 \mathrm{~s}$. 


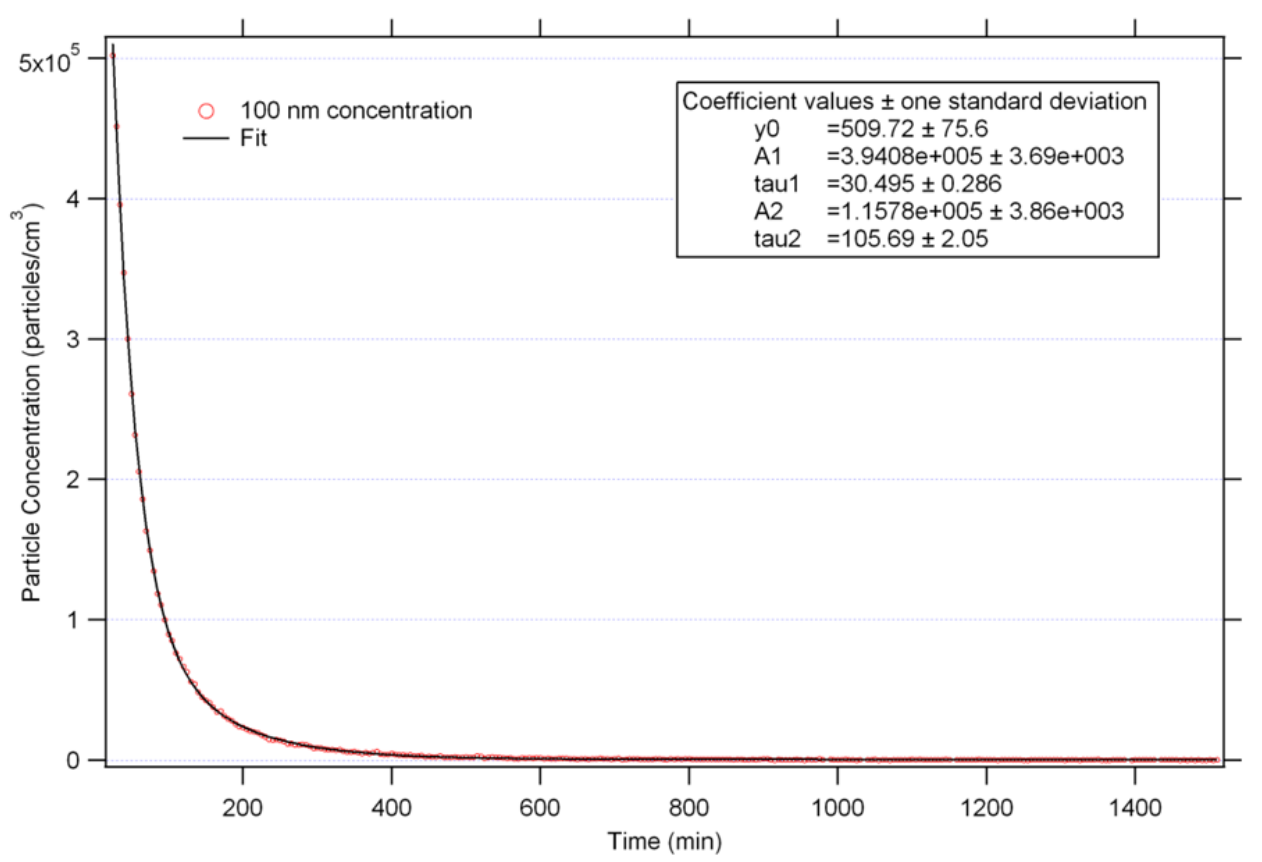

Fig. 5. The loss of $100 \mathrm{~nm}$ particles from pine combustion, with a fit to an offset double exponential function.

of semi-volatile species is either very fast or absent), a better fit would be expected. These results are comparable to other chambers, which were $2.8 \times 10^{-3} \mathrm{~min}^{-1}$ for the Guangzhou chamber (Wang et al., 2014), $3.48 \times 10^{-3} \mathrm{~min}^{-1}$ for the Paul Scherrer Institute chamber (Paulsen et al., 2005), and $1.5 \times 10^{-3} \mathrm{~min}^{-1}$ for the California Institute of Technology chamber (Cocker et al., 2001). More experiments are planned to understand the relationship between initial particle number concentration and the loss rate.

Recent studies simulated the chamber wall loss of particles and vapors from BB smoke (Bian et al., 2015; Trump et al., 2016). Bian et al. (2015) found that $41 \%$ of the initial particle-phase organic mass was lost during the experiments, with $65 \%$ of this loss from direct particle deposition and the remaining $35 \%$ from evaporation of OA and subsequent loss of vapor to the walls. The later mechanism is influenced by dilution during the introduction of particles into the chamber. The shift in the size distribution to larger mobility diameters can also be explained by smaller particles diffusing towards the chamber walls more quickly and coagulating more rapidly, as was observed by Wang et al. (2014) and Takekawa et al. (2003).

Particle loss rates were also studied in detail by several researchers (Carter et al., 2005; Pathak et al., 2007; Pierce et al., 2008; Loza et al., 2012; Nah et al., 2017). Experiments involving wood combustion generally produce BB aerosols in the range of 70-230 nm in mobility diameter, with most of the particles having a mobility diameter of less than $500 \mathrm{~nm}$ (Kamens et al., 1984). This shift can be lessened by using total particle concentrations of less than 25,000 particles $\mathrm{cm}^{-3}$ (McMurry and Grosjean, 1985). We plan to study size distribution of photochemically aged BB aerosol in greater detail as part of our ongoing research goals.

We have not presented size-dependent wall loss rate constants in this work since this is not necessary for measuring optical properties, which is the intended goal of our project. While it is important for determining SOA yield or combustion emission factors, nowhere do we use these loss rates to calculate the optical properties themselves. Instead, number densities are measured with each optical property measurement, and particle losses have been taken into account for each part of the AOPM setup. We have shown here that the lifetime of particles in the chamber (12.4 hours) is sufficiently long compared to our sampling time for optical property measurements (which is on the order of 10 minutes) that losses occurring in the chamber will have minimal effect on the outcome of these experiments.

\section{Light Intensity and Temperature}

The UV lamps (36 in [length], F30T8/350BL/ECO, Sylvania) used for the NCAT chamber simulate the UV portion of the solar spectrum, as shown in Fig. S2. For this range, the FEP film is over $90 \%$ transparent (DuPont, 2010). Average light intensity for the chamber is modeled using the photolysis rate of $\mathrm{NO}_{2}$, which is estimated by the steady-state actinometry method (Wang et al., 2014). The photolysis rate constant $j_{\mathrm{NO} 2}$ is calculated from the measured concentrations of $\mathrm{NO}, \mathrm{NO}_{2}$, and $\mathrm{O}_{3}$ after the lights are turned on and the reaction reached equilibrium, and is given by Eq. (5):

$$
j_{\mathrm{NO}_{2}}=\frac{k_{\mathrm{NO}^{+} \mathrm{O}_{3}}\left[\mathrm{O}_{3}\right][\mathrm{NO}]}{\left[\mathrm{NO}_{2}\right]}
$$

where $[\mathrm{NO}],\left[\mathrm{O}_{3}\right]$, and $\left[\mathrm{NO}_{2}\right]$ represent concentrations (molecules $\mathrm{cm}^{-3}$ ), and $k_{\mathrm{NO}+\mathrm{O} 3}$ is the rate constant of $\mathrm{NO}_{2}$ formation from ozone and $\mathrm{NO}$, which is $k_{\mathrm{NO}+\mathrm{O} 3}=1.9 \times 10^{-14}$ $\mathrm{cm}^{3} \mathrm{~mol}^{-1} \mathrm{sec}^{-1}$ (Burkholder, 2015). The average photolysis rate constant for our chamber is $0.165 \pm 0.005 \mathrm{~min}^{-1}$ at full 
light intensity, as shown in Fig. 6. The maximum $\mathrm{NO}_{2}$ photolysis rate in our chamber is comparable to those reported in other indoor chambers (Cocker et al., 2001; Carter et al., 2005; Paulsen et al., 2005; Leskinen et al., 2015) and comparable to most recent chambers provided in Table 2. When only half of the lights were powered, values of $0.091 \pm 0.005 \mathrm{~min}^{-1}$ and $0.0846 \pm 0.0042 \mathrm{~min}^{-1}$ were obtained for the door side and window side, respectively. The lower rate constant for the window side may be due to the observation windows built into the chamber, which are located near the window side and allow some light to escape.

The effect of excluding the rate of $\mathrm{NO}_{2}$ removal on $j_{\mathrm{NO} 2}$ was also examined. Since the rate constant for the total loss of $\mathrm{NO}_{2}$ is relatively small $\left(4.06 \times 10^{-4} \mathrm{~min}^{-1}\right), j_{\mathrm{NO} 2}$ only decreased by $0.24-0.30 \%$ when this factor was included. As such, while this is not significant for the NCAT chamber, it should be considered for chambers with a lower light intensity or when a chamber is sampled at flow rates that are high relative to the chamber volume.

The actinic flux of the chamber was also measured (Hamilton et al., 2011). The spectrum of the UV lamps, the measured $j$ value for $\mathrm{NO}_{2}$ under several conditions, and the quantum yield and absorption cross section for $\mathrm{NO}_{2}$ (Burkholder, 2015) were used to determine the actinic flux in the region where these lights would be photochemically active towards $\mathrm{NO}_{2}$, which is $296-424 \mathrm{~nm}$. In this method, the spectrum was integrated using the trapezoidal method and normalized to 1 photon $\mathrm{cm}^{-2} \mathrm{~s}^{-1}$ over the $296-424 \mathrm{~nm}$ range. When both banks are engaged, a flux of (7.42 \pm 0.24$)$ $\times 10^{17}$ photons $\mathrm{nm} \mathrm{cm}^{-2} \mathrm{~s}^{-1}$ was found over this wavelength range. When taken over the entire range of the spectrometer $(296.0-516.8 \mathrm{~nm})$, the flux becomes $(7.96 \pm 0.25) \times 10^{17}$ photons $\mathrm{nm} \mathrm{cm}^{-2} \mathrm{~s}^{-1}$. The flux for the bank of lights on the door was $(4.22 \pm 0.24) \times 10^{17}$ and $(4.52 \pm 0.26) \times 10^{17}$ photons $\mathrm{nm} \mathrm{cm} \mathrm{s}^{-1}$ over 296-424 $\mathrm{nm}$ and 296.0$516.8 \mathrm{~nm}$, respectively. Similarly, the set near the windows were $(3.92 \pm 0.18) \times 10^{17}$ and $(4.20 \pm 0.20) \times 10^{17}$ photons $\mathrm{nm} \mathrm{cm} \mathrm{s}^{-1}$ for their respective ranges.

Indoor smog chambers present a potential fire hazard due to the heat generated by the UV lamps that becomes trapped inside the reflective walls of the chamber. With the lamps on, the maximum temperature recorded in the NCAT chamber was under $30^{\circ} \mathrm{C}$ after 5 hours of use, as shown in Fig. S3. The typical change in temperature is less than $10^{\circ} \mathrm{C}$ after 5 hours, with most of the increase occurring in the first hour of operation.

\section{Optical Property Measurements}

Most indirect (and some direct) aerosol optical measurement techniques involve collecting the samples on filters before they can be analyzed. However, the use of filters can affect these measurements due to multiple scattering by the filter itself, the spatial distribution of the particles on the filter, and changes in the morphology of these particles upon deposition (Bond and Bergstrom, 2006;

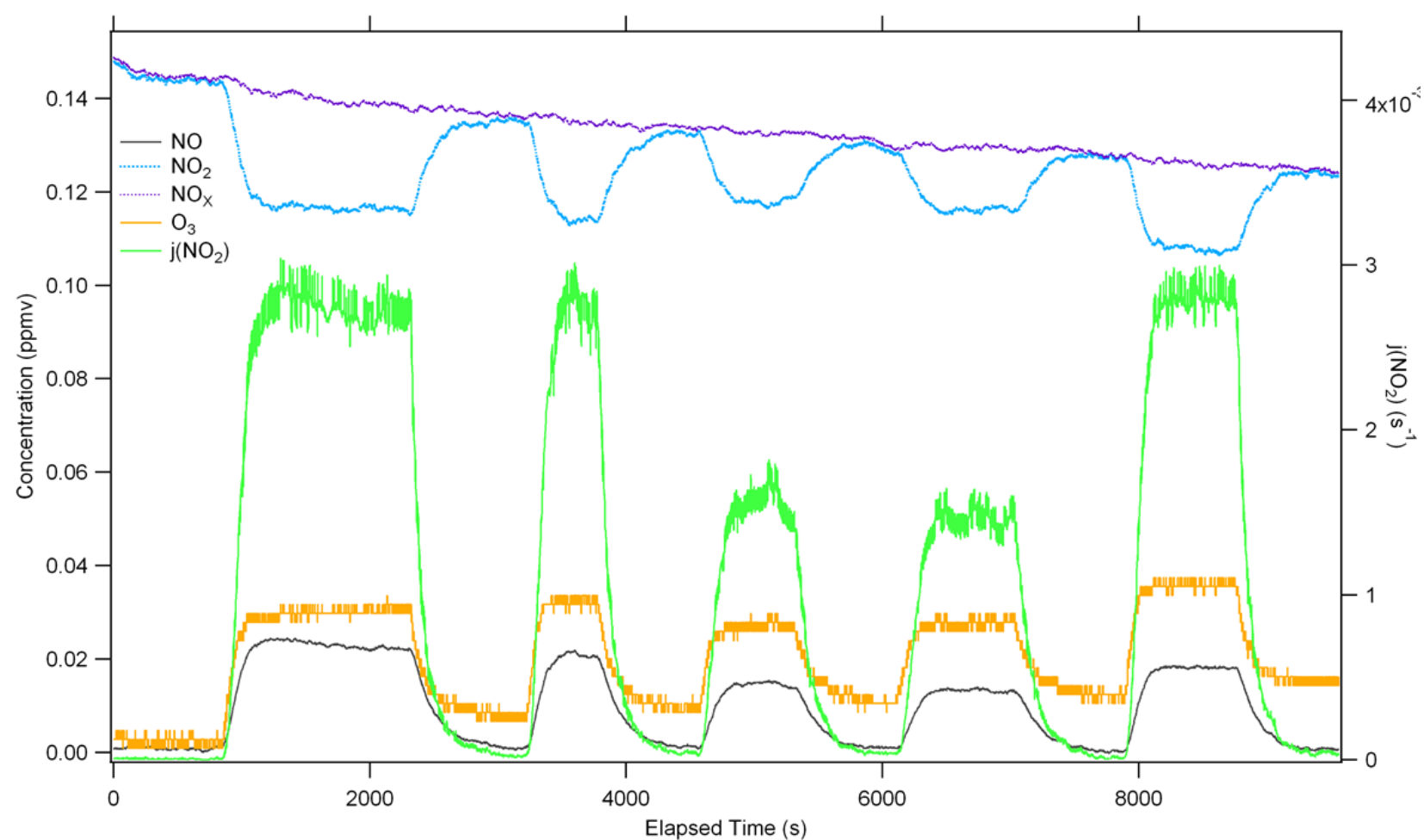

Fig. 6. A plot of the $\mathrm{NO}_{2}$ photolysis rate constant $\left(j_{\mathrm{NO} 2}\right)$ against concentrations of $\mathrm{NO}, \mathrm{NO}_{2}$, and $\mathrm{O}_{3}$. The largest first, second, and last $j_{N O 2}$ peaks correspond to all lights turned on $(100 \%)$, with $j_{N O 2}$ values of $(2.73 \pm 0.086) \times 10^{-3} \mathrm{~s}^{-1},(2.78 \pm$ $0.113) \times 10^{-3} \mathrm{~s}^{-1}$, and $(2.78 \pm 0.068) \times 10^{-3} \mathrm{~s}^{-1}$, respectively. The third and fourth peaks represent the door side and window side of the chamber, respectively, and only use half of the lights $(50 \%)$, with $j_{N O 2}$ values of $(1.56 \pm 0.088) \times 10^{-3} \mathrm{~s}^{-1}$ and $(1.45 \pm 0.068) \times 10^{-3} \mathrm{~s}^{-1}$, respectively. 
Moosmüller et al., 2009). Further, samples collected on filters are more prone to artifacts due to their highly-concentrated nature (Moosmüller et al., 2009). Direct measurements can be taken using a combination of techniques that maintain the state of the aerosol, such as one of the following methods: photoacoustic spectroscopy (PAS) and integrating nephelometry to measure absorption and scattering, respectively, with extinction being the sum of the two; or CRDS and integrating nephelometry to measure extinction and scattering, respectively, while absorption is determined from extinction minus scattering. We use the extinctionminus-scattering method in our lab. For highly absorbing particles, such as BC, this method is quite reasonable (Bond and Bergstrom, 2006), as it has been shown elsewhere (Lewis et al., 2009; Langridge et al., 2013) that PAS can include large errors under certain conditions. Additionally, our CRDS uses tunable lasers that provide a wide range of solar wavelengths (Singh et al., 2016b), while most studies are limited to a single or a few specific wavelengths. The setup in our laboratory will allow us to sample particles directly from the chamber and measure their size distributions and optical properties as a function of aerosol age. To demonstrate this functionality of our combustion-chamber system, we present here preliminary SSA data. As briefly described in the particles sampling and optical property measurement section and with more details in references (Singh et al., 2014, 2016a; Poudel et al., 2017), we used the extinction-minus-scattering technique to measure SSA of BB particles produced by combusting eucalyptus in the tube furnace at $500^{\circ} \mathrm{C}$ before introducing it into the chamber. Extinction and scattering measurements were conducted by sampling the particles from the chamber at the following times after injection: $\sim 90$ minutes (once the size distribution resolves into a single log-normal distribution) for fresh samples, 48 hours for samples aged in the dark, and 10 hours for samples aged with the UV lights following the initial 90 min mixing time. Measurements were done for particle mobility diameters of $200 \mathrm{~nm}, 300 \mathrm{~nm}$, and $400 \mathrm{~nm}$. Fig. 7 shows the SSA for $300 \mathrm{~nm}$ size over a wavelength range of 500 to $570 \mathrm{~nm}$. Results for 200 and $400 \mathrm{~nm}$ particles are provided in the supplementary document Figs. S4(a)S4(b). Table 3 shows the average SSA values for this range. The results show that SSA is nearly independent of wavelength of light in the range used in this experiment; however, it does appear to increase with aging and particle size.

\section{CONCLUSION}

We have shown that the new NCAT indoor combustionchamber system can simulate atmospheric conditions for studying the radiative impacts of $\mathrm{BB}$ aerosols. The chamber was characterized in terms of gas and particle loss rates and other properties that have been evaluated for similar indoor smog chambers. Novel aspects of this chamber include the combination of our custom designed and built instruments and a combustion aerosol generation system that uses a tube furnace to combust small quantities

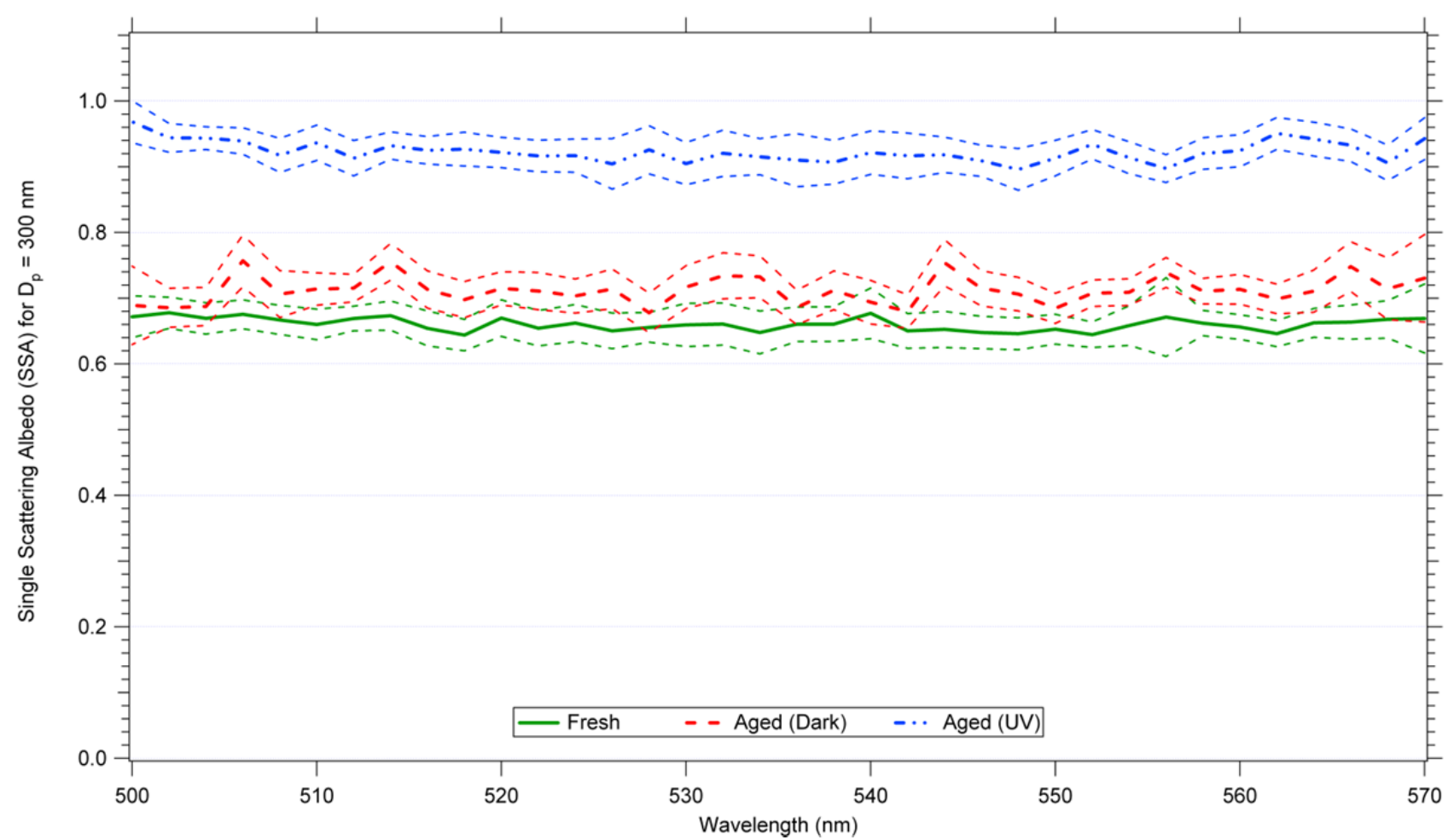

Fig. 7. The single scattering albedo (SSA) aerosol produced by combusting eucalyptus in a tune furnace at $500^{\circ} \mathrm{C}$. Measurements were done 90 minutes after introduction into the chamber, after 48 hours of aging in the dark, and after 10 hours of aging with UV lamps (done in separate experiments) for $300 \mathrm{~nm}$ size particles. Average values are given in Table 3. Dotted lines are the errors. 
Table 3. SSA Values for Eucalyptus BB aerosol combusted at $500^{\circ} \mathrm{C}$.

\begin{tabular}{lllll}
\hline Particle Diameter $(\mathrm{nm})$ & 200 & 300 & 400 & Peak Mobility Diameter (nm) \\
\hline Uncertainty in particle diameter $^{*}$ & $181.2-223.1$ & $271.8-334.7$ & $362.5-446.2$ & \\
Fresh & $0.646 \pm 0.009$ & $0.660 \pm 0.010$ & $0.669 \pm 0.011$ & 131 \\
Aged (Dark) & $0.729 \pm 0.028$ & $0.712 \pm 0.021$ & $0.720 \pm 0.029$ & 322 \\
Aged (UV) & $0.877 \pm 0.017$ & $0.923 \pm 0.016$ & $0.960 \pm 0.020$ & 385 \\
\hline
\end{tabular}

* Poudel et al. (2017).

of fuel under controlled temperature and gas (nitrogen and air) flow conditions, which enables the simulation of different burning stages. The chamber is connected to an SMPS to determine the size distributions of fresh and aged $\mathrm{BB}$ aerosols as they form and change in size over time. To measure their scattering and extinction cross sections using tunable lasers, which provides a wider range of optical wavelengths than previously reported, the BB particles are sampled directly with a cavity ring-down spectrometer and a nephelometer. Using combustion particles from biomass burning, we have identified and fully documented the characteristics of the NCAT chamber in this manuscript. We have also demonstrated this system's ability to measure the size distribution and optical properties of biomass burning aerosols as a function of aging both in the dark and under UV lights. This calibrated system can be used to quantify the effects of fuel type, aging, combustion conditions, combustion stage and humidity on the size distribution and optical and physicochemical properties of biomass burning aerosols.

\section{ACKNOWLEDGEMENTS}

The authors would like to acknowledge Jaime Green and Samin Poudel for their help in the construction of the chamber, Marquin Spann and Dr. Sujeeta Singh for their experimental assistance, and the financial support provided by the National Science Foundation under Grant No. NSFAGS 1555479 to accomplish this work.

\section{SUPPLEMENTARY MATERIAL}

Supplementary data associated with this article can be found in the online version at http://www.aaqr.org.

\section{REFERENCES}

Akagi, S.K., Craven, J.S., Taylor, J.W., McMeeking, G.R., Yokelson, R.J., Burling, I.R., Urbanski, S.P., Wold, C.E., Seinfeld, J.H., Coe, H., Alvarado, M.J. and Weise, D.R. (2012). Evolution of trace gases and particles emitted by a chaparral fire in California. Atmos. Chem. Phys. 12: 1397-1421.

Akimoto, H., Hoshino, M., Inoue, G., Sakamaki, F., Washida, N. and Okuda, M. (1979). Design and characterization of the evacuable and bakable photochemical smog chamber. Environ. Sci. Technol. 13: 471-475.

Andreae, M.O., Andreae, T.W., Annegarn, H., Beer, J., Cachier, H., Le Canut, P., Elbert, W., Maenhaut, W., Salma, I., Wienhold, F.G. and Zenker, T. (1998).
Airborne studies of aerosol emissions from savanna fires in southern Africa: 2. Aerosol chemical composition. $J$. Geophys. Res. 103: 32119-32128.

Andreae, M.O. and Merlet, P. (2001). Emission of trace gases and aerosols from biomass burning. Global Biogeochem. Cycles 15: 955-966.

Babar, Z.B., Park, J.H., Kang, J. and Lim, H.J. (2016). Characterization of a smog chamber for studying formation and physicochemical properties of secondary organic aerosol. Aerosol Air Qual. Res. 16: 3102-3113.

Bian, Q., May, A.A., Kreidenweis, S.M. and Pierce, J.R. (2015). Investigation of particle and vapor wall-loss effects on controlled wood-smoke smog-chamber experiments. Atmos. Chem. Phys. 15: 11027-11045.

Bond, T.C. and Bergstrom, R.W. (2006). Light absorption by carbonaceous particles: An investigative review. Aerosol Sci. Technol. 40: 27-67.

Bond, T.C., Doherty, S.J., Fahey, D.W., Forster, P.M., Berntsen, T., DeAngelo, B.J., Flanner, M.G., Ghan, S., Kärcher, B., Koch, D., Kinne, S., Kondo, Y., Quinn, P.K., Sarofim, M.C., Schultz, M.G., Schulz, M., Venkataraman, C., Zhang, H., Zhang, S., Bellouin, N., Guttikunda, S.K., Hopke, P.K., Jacobson, M.Z., Kaiser, J.W., Klimont, Z., Lohmann, U., Schwarz, J.P., Shindell, D., Storelvmo, T., Warren, S.G. and Zender, C.S. (2013). Bounding the role of black carbon in the climate system: A scientific assessment. J. Geophys. Res. 118: 53805552.

Bruns, E.A., El Haddad, I., Keller, A., Klein, F., Kumar, N.K., Pieber, S.M., Corbin, J.C., Slowik, J.G., Brune, W.H., Baltensperger, U. and Prévôt, A.S.H. (2015). Intercomparison of laboratory smog chamber and flow reactor systems on organic aerosol yield and composition. Atmos. Meas. Tech. 8: 2315-2332.

Burkholder, J.B., Sander, S.P., Abbatt, J., Barker, J.R., Huie, R.E., Kolb, C.E., Kurylo, M.J., Orkin, V.L., Wilmouth, D.M. and Wine, P.H. (2015). Chemical kinetics and photochemical data for use in atmospheric studies, evaluation No. 18. JPL Publication 15-10, Jet Propulsion Laboratory, Pasadena.

Carter, W.P.L., Cocker, D.R., Fitz, D.R., Malkina, I.L., Bumiller, K., Sauer, C.G., Pisano, J.T., Bufalino, C. and Song, C. (2005). A new environmental chamber for evaluation of gas-phase chemical mechanisms and secondary aerosol formation. Atmos. Environ. 39: 77687788.

Cocker, D.R., Flagan, R.C. and Seinfeld, J.H. (2001). State-of-the-art chamber facility for studying atmospheric aerosol chemistry. Environ. Sci. Technol. 35: 2594-2601.

Crump, J.G. and Seinfeld, J.H. (1981). Turbulent deposition 
and gravitational sedimentation of an aerosol in a vessel of arbitrary shape. J. Aerosol Sci. 12: 405-415.

DuPont (2010). DuPont FEP film fluorocarbon film. Information bulletin. Last Access: December 21.

Engelhart, G.J., Hennigan, C.J., Miracolo, M.A., Robinson, A.L. and Pandis, S.N. (2012). Cloud condensation nuclei activity of fresh primary and aged biomass burning aerosol. Atmos. Chem. Phys. 12: 7285-7293.

Formenti, P., Elbert, W., Maenhaut, W., Haywood, J., Osborne, S. and Andreae, M.O. (2003). Inorganic and carbonaceous aerosols during the Southern African Regional Science Initiative (SAFARI 2000) experiment: Chemical characteristics, physical properties, and emission data for smoke from African biomass burning. J. Geophys. Res. 108: 8488.

Gentner, D.R., Isaacman, G., Worton, D.R., Chan, A.W.H., Dallmann, T.R., Davis, L., Liu, S., Day, D.A., Russell, L.M., Wilson, K.R., Weber, R., Guha, A., Harley, R.A. and Goldstein, A.H. (2012). Elucidating secondary organic aerosol from diesel and gasoline vehicles through detailed characterization of organic carbon emissions. Proc. Natl. Acad. Sci. U.S.A. 109: 18318-18323.

Gentner, D.R., Jathar, S.H., Gordon, T.D., Bahreini, R., Day, D.A., El Haddad, I., Hayes, P.L., Pieber, S.M., Platt, S.M., de Gouw, J., Goldstein, A.H., Harley, R.A., Jimenez, J.L., Prévôt, A.S.H. and Robinson, A.L. (2017). Review of urban secondary organic aerosol formation from gasoline and diesel motor vehicle emissions. Environ. Sci. Technol. 51: 1074-1093.

Giordano, M.R. and Asa-Awuku, A. (2014). Rebuttal to correspondence on "changes in droplet surface tension affect the observed hygroscopicity of photochemically aged biomass burning aerosol". Environ. Sci. Technol. 48: 2084-2085.

Grieshop, A.P., Logue, J.M., Donahue, N.M. and Robinson, A.L. (2009). Laboratory investigation of photochemical oxidation of organic aerosol from wood fires 1: Measurement and simulation of organic aerosol evolution. Atmos. Chem. Phys. 9: 1263-1277.

Hallquist, M., Wenger, J.C., Baltensperger, U., Rudich, Y., Simpson, D., Claeys, M., Dommen, J., Donahue, N.M., George, C., Goldstein, A.H., Hamilton, J.F., Herrmann, H., Hoffmann, T., Iinuma, Y., Jang, M., Jenkin, M.E., Jimenez, J.L., Kiendler-Scharr, A., Maenhaut, W., McFiggans, G., Mentel, T.F., Monod, A., Prévôt, A.S.H., Seinfeld, J.H., Surratt, J.D., Szmigielski, R. and Wildt, J. (2009). The formation, properties and impact of secondary organic aerosol: Current and emerging issues. Atmos. Chem. Phys. 9: 5155-5236.

Hamilton, J.F., Rami Alfarra, M., Wyche, K.P., Ward, M.W., Lewis, A.C., McFiggans, G.B., Good, N., Monks, P.S., Carr, T., White, I.R. and Purvis, R.M. (2011). Investigating the use of secondary organic aerosol as seed particles in simulation chamber experiments. Atmos. Chem. Phys. 11: 5917-5929.

Harvey, R.M., Bateman, A.P., Jain, S., Li, Y.J., Martin, S. and Petrucci, G.A. (2016). Optical properties of secondary organic aerosol from cis-3-hexenol and cis-3-hexenyl acetate: Effect of chemical composition, humidity, and phase. Environ. Sci. Technol. 50: 4997-5006.

Hennigan, C.J., Miracolo, M.A., Engelhart, G.J., May, A.A., Presto, A.A., Lee, T., Sullivan, A.P., McMeeking, G.R., Coe, H., Wold, C.E., Hao, W.M., Gilman, J.B., Kuster, W.C., de Gouw, J., Schichtel, B.A., Collett Jr, J.L., Kreidenweis, S.M. and Robinson, A.L. (2011). Chemical and physical transformations of organic aerosol from the photo-oxidation of open biomass burning emissions in an environmental chamber. Atmos. Chem. Phys. 11: 7669-7686.

Hodzic, A., Madronich, S., Bohn, B., Massie, S., Menut, L. and Wiedinmyer, C. (2007). Wildfire particulate matter in Europe during summer 2003: Meso-scale modeling of smoke emissions, transport and radiative effects. Atmos. Chem. Phys. 7: 4043-4064.

Ichoku, C., Giglio, L., Wooster, M.J. and Remer, L.A. (2008). Global characterization of biomass-burning patterns using satellite measurements of fire radiative energy. Remote Sens. Environ. 112: 2950-2962.

IPCC (2013). Climate change 2013: The physical science basis. Contribution of working group I to the fifth assessment report of the intergovernmental panel on climate change. Stocker, T.F., Qin, D., Plattner, G.K., Tignor, M., Allen, S.K., Boschung, J., Nauels, A., Xia, Y., Bex, V. and Midgley, P.M. (Eds.), Cambridge, United Kingdom.

Jimenez, J.L., Canagaratna, M.R., Donahue, N.M., Prevot, A.S.H., Zhang, Q., Kroll, J.H., DeCarlo, P.F., Allan, J.D., Coe, H., Ng, N.L., Aiken, A.C., Docherty, K.S., Ulbrich, I.M., Grieshop, A.P., Robinson, A.L., Duplissy, J., Smith, J.D., Wilson, K.R., Lanz, V.A., Hueglin, C., Sun, Y.L., Tian, J., Laaksonen, A., Raatikainen, T., Rautiainen, J., Vaattovaara, P., Ehn, M., Kulmala, M., Tomlinson, J.M., Collins, D.R., Cubison, M.J., Dunlea, J., Huffman, J.A., Onasch, T.B., Alfarra, M.R., Williams, P.I., Bower, K., Kondo, Y., Schneider, J., Drewnick, F., Borrmann, S., Weimer, S., Demerjian, K., Salcedo, D., Cottrell, L., Griffin, R., Takami, A., Miyoshi, T., Hatakeyama, S., Shimono, A., Sun, J.Y., Zhang, Y.M., Dzepina, K., Kimmel, J.R., Sueper, D., Jayne, J.T., Herndon, S.C., Trimborn, A.M., Williams, L.R., Wood, E.C., Middlebrook, A.M., Kolb, C.E., Baltensperger, U. and Worsnop, D.R. (2009). Evolution of organic aerosols in the atmosphere. Science 326: 1525-1529.

Kalogridis, A.C., Popovicheva, O.B., Engling, G., Diapouli, E., Kawamura, K., Tachibana, E., Ono, K., Kozlov, V.S. and Eleftheriadis, K. (2018). Smoke aerosol chemistry and aging of Siberian biomass burning emissions in a large aerosol chamber. Atmos. Environ. 185: 15-28.

Kamens, R.M., Rives, G.D., Perry, J.M., Bell, D.A., Paylo, R.F., Goodman, R.G. and Claxton, L.D. (1984). Mutagenic changes in dilute wood smoke as it ages and reacts with ozone and nitrogen dioxide. An outdoor chamber study. Environ. Sci. Technol. 18: 523-530.

Kanakidou, M., Seinfeld, J.H., Pandis, S.N., Barnes, I., Dentener, F.J., Facchini, M.C., van Dingenen, R., Ervens, B., Nenes, A., Nielsen, C.J., Swietlicki, E., Putaud, J.P., Balkanski, Y., Fuzzi, S., Horth, J., Moortgat, G.K., Winterhalter, R., Myhre, C.E.L., Tsigaridis, K., Vignati, 
E., Stephanou, E.G. and Wilson, J. (2005). Organic aerosol and global climate modelling: A review. Atmos. Chem. Phys. 5: 1053-1123.

Kim, H. and Paulson, S.E. (2013). Real refractive indices and volatility of secondary organic aerosol generated from photooxidation and ozonolysis of limonene, $\alpha$-pinene and toluene. Atmos. Chem. Phys. 13: 7711-7723.

Koch, D., Menon, S., Genio, A.D., Ruedy, R., Alienov, I. and Schmidt, G.A. (2009). Distinguishing aerosol impacts on climate over the past century. J. Clim. 22: 2659-2677.

La, Y.S., Camredon, M., Ziemann, P.J., Valorso, R., Matsunaga, A., Lannuque, V., Lee-Taylor, J., Hodzic, A., Madronich, S. and Aumont, B. (2016). Impact of chamber wall loss of gaseous organic compounds on secondary organic aerosol formation: Explicit modeling of SOA formation from alkane and alkene oxidation. Atmos. Chem. Phys. 16: 1417-1431.

Lamarque, J.F., Bond, T.C., Eyring, V., Granier, C., Heil, A., Klimont, Z., Lee, D., Liousse, C., Mieville, A., Owen, B., Schultz, M.G., Shindell, D., Smith, S.J., Stehfest, E., Van Aardenne, J., Cooper, O.R., Kainuma, M., Mahowald, N., McConnell, J.R., Naik, V., Riahi, K. and van Vuuren, D.P. (2010). Historical (1850-2000) gridded anthropogenic and biomass burning emissions of reactive gases and aerosols: Methodology and application. Atmos. Chem. Phys. 10: 7017-7039.

Langridge, J.M., Richardson, M.S., Lack, D.A., Brock, C.A. and Murphy, D.M. (2013). Limitations of the photoacoustic technique for aerosol absorption measurement at high relative humidity. Aerosol Sci. Technol. 47: 1163-1173.

Leskinen, A., Yli-Pirilä, P., Kuuspalo, K., Sippula, O., Jalava, P., Hirvonen, M.R., Jokiniemi, J., Virtanen, A., Komppula, M. and Lehtinen, K.E.J. (2015). Characterization and testing of a new environmental chamber. Atmos. Meas. Tech. 8: 2267-2278.

Levin, E.J.T., McMeeking, G.R., Carrico, C.M., Mack, L.E., Kreidenweis, S.M., Wold, C.E., Moosmüller, H., Arnott, W.P., Hao, W.M., Collett, J.L. and Malm, W.C. (2010). Biomass burning smoke aerosol properties measured during Fire Laboratory at Missoula Experiments (FLAME). J. Geophys. Res. 115: D18210.

Lewis, K.A., Arnott, W.P., Moosmüller, H., Chakrabarty, R.K., Carrico, C.M., Kreidenweis, S.M., Day, D.E., Malm, W.C., Laskin, A., Jimenez, J.L., Ulbrich, I.M., Huffman, J.A., Onasch, T.B., Trimborn, A., Liu, L. and Mishchenko, M.I. (2009). Reduction in biomass burning aerosol light absorption upon humidification: Roles of inorganically-induced hygroscopicity, particle collapse, and photoacoustic heat and mass transfer. Atmos. Chem. Phys. 9: 8949-8966.

Liousse, C., Guillaume, B., Grégoire, J.M., Mallet, M., Galy, C., Pont, V., Akpo, A., Bedou, M., Castéra, P., Dungall, L., Gardrat, E., Granier, C., Konaré, A., Malavelle, F., Mariscal, A., Mieville, A., Rosset, R., Serça, D., Solmon, F., Tummon, F., Assamoi, E., Yoboué, V. and van Velthoven, P. (2010). Updated African biomass burning emission inventories in the framework of the AMMAIDAF program, with an evaluation of combustion aerosols. Atmos. Chem. Phys. 10: 9631-9646.

Liu, S., Aiken, A.C., Arata, C., Dubey, M.K., Stockwell, C.E., Yokelson, R.J., Stone, E.A., Jayarathne, T., Robinson, A.L., DeMott, P.J. and Kreidenweis, S.M. (2014). Aerosol single scattering albedo dependence on biomass combustion efficiency: Laboratory and field studies. Geophys. Res. Lett. 41: 742-748.

Loza, C.L., Chhabra, P.S., Yee, L.D., Craven, J.S., Flagan, R.C. and Seinfeld, J.H. (2012). Chemical aging of $m$ xylene secondary organic aerosol: Laboratory chamber study. Atmos. Chem. Phys. 12: 151-167.

Mack, L.A., Levin, E.J.T., Kreidenweis, S.M., Obrist, D., Moosmüller, H., Lewis, K.A., Arnott, W.P., McMeeking, G.R., Sullivan, A.P., Wold, C.E., Hao, W.M., Collett Jr, J.L. and Malm, W.C. (2010). Optical closure experiments for biomass smoke aerosols. Atmos. Chem. Phys. 10: 9017-9026.

Mack, L.E. (2008). Cavity ring-down sectroscopy and the retrieval of aerosol optical properties from biomass burning during FLAME 2. Colorado State University, CO, USA.

May, A.A., Levin, E.J.T., Hennigan, C.J., Riipinen, I., Lee, T., Collett, J.L., Jimenez, J.L., Kreidenweis, S.M. and Robinson, A.L. (2013). Gas-particle partitioning of primary organic aerosol emissions: 3 . Biomass burning. J. Geophys. Res. 118: 11327-11338.

McMeeking, G.R., Kreidenweis, S.M., Baker, S., Carrico, C.M., Chow, J.C., Collett, J.L., Hao, W.M., Holden, A.S., Kirchstetter, T.W., Malm, W.C., Moosmüller, H., Sullivan, A.P. and Wold, C.E. (2009). Emissions of trace gases and aerosols during the open combustion of biomass in the laboratory. J. Geophys. Res. 114: D19210.

McMurry, P.H. and Grosjean, D. (1985). Gas and aerosol wall losses in Teflon film smog chambers. Environ. Sci. Technol. 19: 1176-1182.

Moosmüller, H., Chakrabarty, R.K. and Arnott, W.P. (2009). Aerosol light absorption and its measurement: A review. J. Quant. Spectrosc. Radiat. Transfer 110: 844-878.

Nah, T., McVay, R.C., Pierce, J.R., Seinfeld, J.H. and Ng, N.L. (2017). Constraining uncertainties in particle-wall deposition correction during SOA formation in chamber experiments. Atmos. Chem. Phys. 17: 2297-2310.

Pathak, R.K., Stanier, C.O., Donahue, N.M. and Pandis, S.N. (2007). Ozonolysis of $\alpha$-pinene at atmospherically relevant concentrations: Temperature dependence of aerosol mass fractions (yields). J. Geophys. Res. 112: D03201.

Paulsen, D., Dommen, J., Kalberer, M., Prévôt, A.S.H., Richter, R., Sax, M., Steinbacher, M., Weingartner, E. and Baltensperger, U. (2005). Secondary organic aerosol formation by irradiation of 1,3,5-trimethylbenzene- $\mathrm{NO}_{\mathrm{x}}$ $\mathrm{H}_{2} \mathrm{O}$ in a new reaction chamber for atmospheric chemistry and physics. Environ. Sci. Technol. 39: 2668-2678.

Pierce, J.R., Engelhart, G.J., Hildebrandt, L., Weitkamp, E.A., Pathak, R.K., Donahue, N.M., Robinson, A.L., Adams, P.J. and Pandis, S.N. (2008). Constraining particle evolution from wall losses, coagulation, and condensationevaporation in smog-chamber experiments: Optimal estimation based on size distribution measurements. 
Aerosol Sci. Technol. 42: 1001-1015.

Poudel, S., Fiddler, M.N., Smith, D., Flurchick, K.M. and Bililign, S. (2017). Optical properties of biomass burning aerosols: Comparison of experimental measurements and t-matrix calculations. Atmosphere 8: 228.

Roberts, G.J. and Wooster, M.J. (2008). Fire detection and fire characterization over Africa using Meteosat SEVIRI. IEEE Trans. Geosci. Remote Sens. 46: 1200-1218.

Roberts, G., Wooster, M.J. and Lagoudakis, E. (2009). Annual and diurnal African biomass burning temporal dynamics. Biogeosciences 6: 849-866.

Robinson, A.L., Donahue, N.M., Shrivastava, M.K., Weitkamp, E.A., Sage, A.M., Grieshop, A.P., Lane, T.E., Pierce, J.R. and Pandis, S.N. (2007). Rethinking organic aerosols: Semivolatile emissions and photochemical aging. Science 315: 1259-1262.

Schick, S.F., Farraro, K.F., Fang, J., Nasir, S., Kim, J., Lucas, D., Wong, H., Balmes, J., Giles, D.K. and Jenkins, B. (2012). An apparatus for generating aged cigarette smoke for controlled human exposure studies. Aerosol Sci. Technol. 46: 1246-1255.

Schultz, M.G., Heil, A., Hoelzemann, J.J., Spessa, A., Thonicke, K., Goldammer, J.G., Held, A.C., Pereira, J.M.C. and van het Bolscher, M. (2008). Global wildland fire emissions from 1960 to 2000. Global Biogeochem. Cycles 22: GB2002.

Shi, Y., Matsunaga, T. and Yamaguchi, Y. (2015). Highresolution mapping of biomass burning emissions in three tropical regions. Environ. Sci. Technol. 49: 1080610814.

Singh, A., Srivastava, R., Rastogi, N. and Singh, D. (2016a). Absorbing and scattering aerosols over the source region of biomass burning emissions: Implications in the assessment of optical and radiative properties. Atmos. Environ. 127: 61-68.

Singh, S., Fiddler, M.N., Smith, D. and Bililign, S. (2014). Error analysis and uncertainty in the determination of aerosol optical properties using cavity ring-down spectroscopy, integrating nephelometry, and the extinctionminus-scattering method. Aerosol Sci. Technol. 48: 13451359.

Singh, S., Fiddler, M.N. and Bililign, S. (2016b). Measurement of size-dependent single scattering albedo of fresh biomass burning aerosols using the extinctionminus-scattering technique with a combination of cavity ring-down spectroscopy and nephelometry. Atmos. Chem. Phys. 16: 13491-13507.

Takekawa, H., Minoura, H. and Yamazaki, S. (2003). Temperature dependence of secondary organic aerosol formation by photo-oxidation of hydrocarbons. Atmos. Environ. 37: 3413-3424.

Tiitta, P., Leskinen, A., Hao, L., Yli-Pirilä, P., Kortelainen, M., Grigonyte, J., Tissari, J., Lamberg, H., Hartikainen, A., Kuuspalo, K., Kortelainen, A.M., Virtanen, A., Lehtinen, K.E.J., Komppula, M., Pieber, S., Prévôt, A.S.H., Onasch, T.B., Worsnop, D.R., Czech, H., Zimmermann, R., Jokiniemi, J. and Sippula, O. (2016). Transformation of logwood combustion emissions in a smog chamber: Formation of secondary organic aerosol and changes in the primary organic aerosol upon daytime and nighttime aging. Atmos. Chem. Phys. 16: 1325113269.

Tissari, J., Lyyränen, J., Hytönen, K., Sippula, O., Tapper, U., Frey, A., Saarnio, K., Pennanen, A.S., Hillamo, R., Salonen, R.O., Hirvonen, M.R. and Jokiniemi, J. (2008). Fine particle and gaseous emissions from normal and smouldering wood combustion in a conventional masonry heater. Atmos. Environ. 42: 7862-7873.

Torvela, T., Tissari, J., Sippula, O., Kaivosoja, T., Leskinen, J., Virén, A., Lähde, A. and Jokiniemi, J. (2014). Effect of wood combustion conditions on the morphology of freshly emitted fine particles. Atmos. Environ. 87: 65-76.

Trump, E.R., Epstein, S.A., Riipinen, I. and Donahue, N.M. (2016). Wall effects in smog chamber experiments: A model study. Aerosol Sci. Technol. 50: 1180-1200.

van der Werf, G.R., Randerson, J.T., Giglio, L., Collatz, G.J., Mu, M., Kasibhatla, P.S., Morton, D.C., DeFries, R.S., Jin, Y. and van Leeuwen, T.T. (2010). Global fire emissions and the contribution of deforestation, savanna, forest, agricultural, and peat fires (1997-2009). Atmos. Chem. Phys. 10: 11707-11735.

Wang, J., Doussin, J.F., Perrier, S., Perraudin, E., Katrib, Y., Pangui, E. and Picquet-Varrault, B. (2011). Design of a new multi-phase experimental simulation chamber for atmospheric photosmog, aerosol and cloud chemistry research. Atmos. Meas. Tech. 4: 2465-2494.

Wang, X., Liu, T., Bernard, F., Ding, X., Wen, S., Zhang, Y., Zhang, Z., He, Q., Lü, S., Chen, J., Saunders, S. and $\mathrm{Yu}$, J. (2014). Design and characterization of a smog chamber for studying gas-phase chemical mechanisms and aerosol formation. Atmos. Meas. Tech. 7: 301-313.

Weitkamp, E.A., Sage, A.M., Pierce, J.R., Donahue, N.M. and Robinson, A.L. (2007). Organic aerosol formation from photochemical oxidation of diesel exhaust in a smog chamber. Environ. Sci. Technol. 41: 6969-6975.

Wu, S., Lü, Z., Hao, J., Zhao, Z., Li, J., Takekawa, H., Minoura, H. and Yasuda, A. (2007). Construction and characterization of an atmospheric simulation smog chamber. Adv. Atmos. Sci. 24: 250-258.

Yokelson, R.J., Crounse, J.D., DeCarlo, P.F., Karl, T., Urbanski, S., Atlas, E., Campos, T., Shinozuka, Y., Kapustin, V., Clarke, A.D., Weinheimer, A., Knapp, D.J., Montzka, D.D., Holloway, J., Weibring, P., Flocke, F., Zheng, W., Toohey, D., Wennberg, P.O., Wiedinmyer, C., Mauldin, L., Fried, A., Richter, D., Walega, J., Jimenez, J.L., Adachi, K., Buseck, P.R., Hall, S.R. and Shetter, R. (2009). Emissions from biomass burning in the Yucatan. Atmos. Chem. Phys. 9: 5785-5812.

Zauscher, M.D., Wang, Y., Moore, M.J.K., Gaston, C.J. and Prather, K.A. (2013). Air quality impact and physicochemical aging of biomass burning aerosols during the 2007 San Diego wildfires. Environ. Sci. Technol. 47: 7633-7643.

Zhang, Q., Jimenez, J.L., Canagaratna, M.R., Ulbrich, I.M., Ng, N.L., Worsnop, D.R. and Sun, Y. (2011). Understanding atmospheric organic aerosols via factor analysis of aerosol mass spectrometry: A review. Anal. Bioanal.Chem. 401: 3045-3067. 
Zhang, X., Cappa, C.D., Jathar, S.H., McVay, R.C., Ensberg, J.J., Kleeman, M.J. and Seinfeld, J.H. (2014). Influence of vapor wall loss in laboratory chambers on yields of secondary organic aerosol. Proc. Natl. Acad. Sci. U.S.A. 111: 5802-5807.
Received for review, June 30, 2018 Revised, September 24, 2018 Accepted, October 2, 2018 